University of Florida Levin College of Law

UF Law Scholarship Repository

UF Law Faculty Publications

Faculty Scholarship

Fall 2002

\title{
Estate Tax Repeal: Through the Looking Glass
}

Karen C. Burke

University of Florida Levin College of Law, burkek@law.ufl.edu

Grayson M.P. McCouch

University of Florida Levin College of Law, gmccouch@law.ufl.edu

Follow this and additional works at: https://scholarship.law.ufl.edu/facultypub

Part of the Estates and Trusts Commons, and the Taxation-Federal Estate and Gift Commons

\section{Recommended Citation}

Karen C. Burke \& Grayson M.P. McCouch, Estate Tax Repeal: Through the Looking Glass, 22 Va. Tax Rev. 187 (2002), available at http://scholarship.law.ufl.edu/facultypub/557

This Article is brought to you for free and open access by the Faculty Scholarship at UF Law Scholarship Repository. It has been accepted for inclusion in UF Law Faculty Publications by an authorized administrator of UF Law Scholarship Repository. For more information, please contact kaleita@law.ufl.edu. 


\title{
ESTATE TAX REPEAL: THROUGH THE LOOKING GLASS
}

\author{
Karen C. Burke* \\ Grayson M.P. McCouch**
}

\section{TABLE OF CONTENTS}

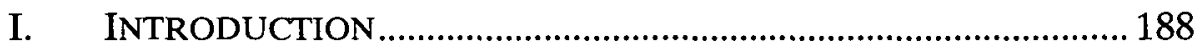

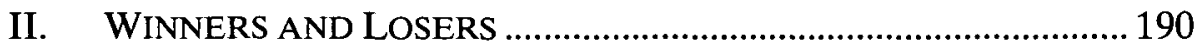

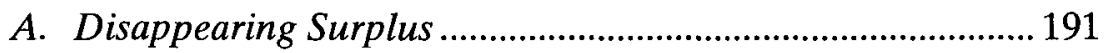

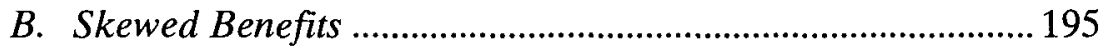

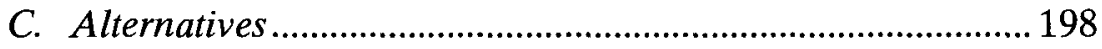

III. CARRYOVER BASIS: ILLUSIONS AND REALITIES..................... 201

A. Disappearing Gain.......................................................... 202

B. Rewards of Marriage ....................................................... 206

C. An Unlevel Playing Field: Pensions and Life Insurance..... 210

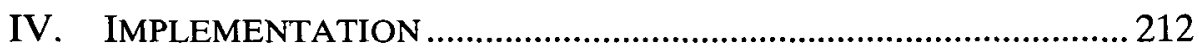

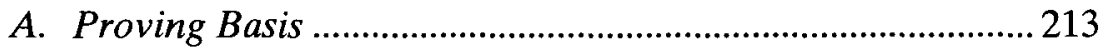

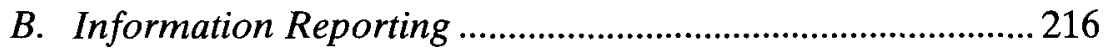

C. Allocation of Basis Increase ................................................220

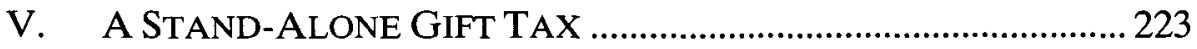

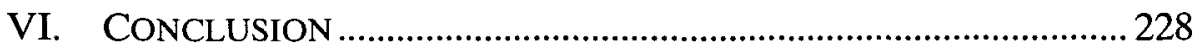

* Warren Distinguished Professor, University of San Diego School of Law.

"* Professor, University of San Diego School of Law.

This article grew out of a presentation at a November 2001 meeting of the Virginia Tax Study Group. We would like to thank Professor Edwin S. Cohen and participants in the Study Group for their helpful comments. We also acknowledge generous research support from the University of San Diego School of Law. 


\section{INTRODUCTION}

In recent years the federal estate, gift, and generation-skipping transfer taxes have come under sustained attack. Opponents have launched an all-out campaign to abolish the wealth transfer taxes, branding them as unfair, counterproductive, and even immoral. The abolitionist cause has gained substantial support among the general public and in Congress. In 1999 and again in 2000, Congress voted to repeal the estate tax, though both attempts ended, predictably, with a presidential veto.' During the 2000 presidential campaign, thencandidate George W. Bush aligned himself with the abolitionists, and with the inauguration of the Bush administration in 2001 the prospect of estate tax repeal became real. Promptly after assuming office, President Bush, emboldened by a favorable budget outlook, proposed a program of massive tax cuts with estate tax repeal as a central component. Congress acted expeditiously on the proposal, and on June 7, 2001, President Bush signed the Economic Growth and Tax Relief Reconciliation Act of $2001^{2}$ (2001 Act or Act) into law.

The 2001 Act is a remarkable piece of legislation. It promises dramatic reductions in income and estate taxes over a nine-year phase-in period, culminating in 2010 with complete repeal of the estate tax and introduction of a new carryover basis regime for inherited property. ${ }^{3}$ Interestingly, though, it retains the gift tax even after repeal of the estate and generation-skipping transfer taxes. By far the most arresting feature of the Act is the "sunset" provision, which automatically terminates the Act's substantive changes at the end of 2010 and reinstates prior law for 2011 and subsequent years. ${ }^{4}$ In effect, the sunset provision transforms the Act's large-scale tax cuts

1 See Taxpayer Refund and Relief Act of 1999, H.R. 2488, 106th Cong. $§ 601$; Death Tax Elimination Act of 2000, H.R. 8, 106th Cong. $§ 101$.

2 Economic Growth and Tax Relief Reconciliation Act of 2001, Pub. L. No. 107-16, 115 Stat. 38 (codified as amended in scattered sections of I.R.C.).

${ }^{3}$ See id. $\$ \S 501$ (terminating estate and generation-skipping transfer taxes after 2009), 541 (terminating deathtime basis step-up after 2009), 542 (introducing carryover basis for property acquired from a decedent after 2009).

${ }^{4}$ See id. $\$ 901$ (b) (reinstating prior law for 2011 and subsequent years "as if [the 2001 Act] had never been enacted"). This provision was added in the conference agreement to avoid a procedural challenge under the Senate's "Byrd Rule," which requires a $60 \%$ supermajority for legislation that affects revenues beyond the ten-year budget horizon. See William G. Gale \& Samara R. Potter, An Economic Evaluation of the Economic Growth and Tax Relief Reconciliation Act of 2001, 55 NAT'L TAX J. 133,137 (2002). The conference agreement passed the Senate by a 58-33 vote, two votes short of the sixty votes that would have been necessary to waive the Byrd Rule. 
into a temporary measure and leaves open the question of whether to make those cuts permanent.

Virtually no one expects to see the estate tax in its current form spring back into force in 2011..$^{5}$ Instead, the 2001 Act is best viewed as an unstable truce between two contending political camps: on one hand, the root-and-branch tax-cutters who are determined to abolish the estate tax permanently, in several strokes if the goal cannot be achieved all at once; and on the other hand, skeptics who concede the need for estate tax reform but balk at outright repeal. Both camps have introduced bills staking out their respective positions, ${ }^{6}$ and the outcome of the battle over the future of the estate tax remains uncertain. In the meantime, political and economic developments have already begun to reshape the estate tax debate. Volatility in capital markets, a deteriorating economic outlook, and the looming threat of international terrorism have contributed to a pervasive atmosphere of uncertainty. The hefty budget surpluses projected at the beginning of 2001 have evaporated and turned into deficits. Nevertheless, as changed circumstances prompt a widespread rethinking of national priorities, abolitionists in the Bush administration and in Congress continue to press for permanent estate tax repeal. Indeed, this appears to be the first administration ever to launch a major war effort by attacking the federal taxation of inherited property. ${ }^{7}$

In this article, we consider the implications of repealing the estate tax and replacing it with a carryover basis regime, assuming for the sake of argument that the 2001 Act's treatment of property transferred at death may become permanent through repeal of the

5 See Gale \& Potter, supra note 4, at 138 ("Virtually no one believes the bill will sunset as written.").

${ }^{6}$ Compare Tax Relief Guarantee Act of 2002, H.R. 586, 107th Cong. (proposing repeal of sunset provision for entire $2001 \mathrm{Act}$ ), and Permanent Death Tax Repeal Act of 2002, H.R. 2143, 107th Cong. (proposing repeal of sunset provision for estate tax provisions), with H.R. 5008, 107th Cong. (2002) (proposing retention of wealth transfer taxes with $\$ 3,500,000$ exemption and $50 \%$ top marginal rate).

7 The modern estate tax was enacted in 1916, during the military buildup for World War I. Throughout the nation's early history, federal estate or inheritance taxes were imposed "primarily to finance wars or the threat of war." STAFF OF JOINT COMm. ON TAXATION, 107th Cong., Description AND ANAlysis of PRESENT LAW and Proposals Relating to Federal Estate and Gift Taxation 10-11 (Joint Comm. Print 2001); see also William G. Gale \& Joel Slemrod, Overview, in Rethinking Estate And Gift TAXATION 1, 14 (William G. Gale et al. eds., 2001) ("Like its precursors, the modern estate tax originated in a time of war preparation, if not war itself."). 
sunset provision. The concept of carryover basis for inherited property is not new, but it has a checkered past. A previous experiment with carryover basis, enacted in 1976 and terminated a few years later, ${ }^{8}$ has been described as "one of the greatest legislative fiascoes in the history of the income tax." In coupling carryover basis with repeal of the estate tax, the 2001 Act marks a major departure from the 1976 Act, but it remains to be seen whether the new carryover basis regime will prove more effective or long-lived than its predecessor. ${ }^{10}$

In Part II, we examine the revenue and distributional impact of estate tax repeal, before turning in the remaining parts to a closer analysis of the 2001 Act's substantive provisions concerning gifts and bequests. Part III discusses the scope and structure of the new carryover basis regime, focusing on the exemptions that allow a deathtime basis step-up for large amounts of appreciated property in even the wealthiest estates. Part IV explores problems of implementation and raises questions about the practicability of the new carryover basis regime. Part $V$ examines the notion of retaining a gift tax in the absence of an estate tax and argues that this aspect of the Act is unlikely to remain in force. The conclusion offers a critical assessment of the Act's carryover basis regime as an alternative to the current estate tax.

\section{WINNERS AND LOSERS}

Proponents of the 2001 Act have portrayed the tax cuts as affordable and necessary to stimulate a faltering economy while emphasizing that the Act provides across-the-board tax cuts for households at all income levels." These claims, however, are

${ }^{8}$ See Tax Reform Act of 1976, Pub. L. No. 94-455, § 2005, 90 Stat. 1520, 1872-77 (adding former section 1023) [hereinafter former I.R.C. $\S 1023$ ]. The carryover basis provisions of the 1976 Act were amended in 1978 and ultimately repealed with retroactive effect in 1980. See Revenue Act of 1978, Pub. L. No. 95-600, § 515, 92 Stat. 2763, 2884 (amending former section 1023); Crude Oil Windfall Profit Tax Act of 1980, Pub. L. No. 96-223, § 401(a), 94 Stat. 229, 299 (repealing former section 1023).

Lawrence Zelenak, Taxing Gains at Death, 46 VAND. L. REV. 361, 365 (1993).

${ }^{10}$ For a general discussion of carryover basis and a comparison with a deathtime gains tax, see Karen C. Burke \& Grayson M.P. McCouch, Death Without Taxes?, 20 VA. TAX REV. 499 (2001).

${ }^{11}$ In his 2001 State of the Union address, President Bush announced, "In my plan, no one is targeted in or targeted out. Everyone who pays income taxes will get relief." Address Before a Joint Session of the Congress on Administration Goals, 37 
incomplete and misleading. Estate tax repeal, even if coupled with a carryover basis regime, represents a major windfall for a small group of very high-income taxpayers and does nothing to stimulate consumption in the short term. Even in the long term, the effects of estate tax repeal on work effort, saving, and investment remain uncertain. $^{12}$ Moreover, if the sunset provision is repealed and the tax cuts become permanent, as the abolitionists urge, the resulting revenue losses will exacerbate an increasingly dire long-term budget outlook. ${ }^{13}$ As the revenue and distributional implications of the Act become clearer, the abolitionist agenda may lose much of its initial populist appeal.

\section{A. Disappearing Surplus}

In January 2001, the Congressional Budget Office (CBO) projected a unified budget surplus of $\$ 5.6$ trillion for fiscal years 2002 2011 . $^{14}$ Promptly after taking office, President Bush announced his intention to use a large portion of the surplus to pay for an ambitious program of tax cuts that eventually came to fruition in the 2001 Act. He portrayed the proposed tax cuts as prudent ${ }^{15}$ and insisted that they would leave ample room in the budget to protect social security trust funds, to pay down outstanding federal debt, and to provide a residual fund for unexpected needs. ${ }^{16}$ At first glance, the projected $\$ 5.6$ trillion surplus may seem more than adequate to pay for $\$ 1.35$ trillion of tax cuts, even after subtracting the $\$ 2.5$ trillion "off-budget" social security surplus. On closer examination, however, the budget outlook

WEEKLy COMP. PRES. DOC. 351, $354-55$ (Feb. 27, 2001) [hereinafter State of the Union]; see also Remarks on Signing the Economic Growth and Tax Relief Reconciliation Act of 2001, 37 WEEkLY COMP. PRES. DOC. 858, 858 (June 7, 2001) (describing the 2001 Act as "[a]cross the board tax relief").

12 See Gale \& Slemrod, supra note 7, at 43-50.

13 See Gale \& Potter, supra note 4, at 133 (describing the 2001 Act as "not fiscally sustainable").

${ }^{14}$ See Cong. Budget Office, 107Th Cong., The Budget and ECONomic OUTLOOK: FISCAL YEARS 2002-2011, at 2 tbl.1-1 (2001).

15 See State of the Union, supra note 11, at 354 (stating that "[w]e should approach our Nation's budget as any prudent family would," asserting that "the growing surplus exists because taxes are too high and Government is charging more than it needs," and describing proposed tax cuts as "just right" - not "too big," not "too small").

${ }^{16}$ See $i d$. at 352,354 (insisting that the proposal would "protect[] all $\$ 2.6$ trillion of the Social Security surplus" and permit the government "to pay down $\$ 2$ trillion in debt during the next 10 years" while maintaining "a contingency fund for emergencies or additional spending needs"). 
appears far bleaker than the CBO projections might seem to suggest, and the effects of the Act are likely to make matters even worse in the long term.

In projecting a $\$ 5.6$ trillion surplus, the CBO does not purport to offer a realistic forecast or prediction of future outcomes. ${ }^{17}$ This is not to suggest that the $\mathrm{CBO}$ projections are inaccurate or unreliable, but merely that they are constructed for a specific purpose and should be used with care. ${ }^{18}$ To put the CBO projections in perspective, it is helpful to note that they are constrained by a ten-year budget horizon, which ignores more remote conditions and events. Thus, the projected short-term surplus should be considered in the context of the long-term "fiscal gap" resulting from projected deficits beyond the ten-year horizon. ${ }^{19}$ This point is particularly telling in the case of social security revenues and expenditures, which are included in the unified budget projections on a cash-flow basis. ${ }^{20}$ Since annual program revenues (primarily from payroll tax collections) currently exceed expenditures (primarily for benefits), the resulting surpluses account for a substantial portion - nearly $\$ 2.5$ trillion - of the projected $\$ 5.6$ trillion unified budget surplus for fiscal years 2002$2011 .^{21}$ If current policies remain unchanged, the social security trust funds are expected to start running annual deficits as large numbers of

17 See Cong. Budget Office, 107Th Cong., The Budget And Economic OUTLOOK: FISCAL YEARS 2002-2011, at 7 (noting that CBO baseline "is not 'realistic,' because tax and spending policies will change over time," nor is it "intended to be a forecast of future budgetary outcomes").

${ }^{18}$ The CBO baseline serves as "a neutral benchmark that the Congress can use to measure the effects of proposed changes in spending and revenue policies," and is constructed according to prescribed rules. Id. at 5. For detailed analysis and criticism of the CBO baseline, see Alan J. Auerbach et al., The Budget Outlook and Options for Fiscal Policy, 95 TAx Notes 1639, 1640-48, 1644 n.4 (June 10, 2002) (noting that criticisms are leveled not at the CBO per se but at "the laws that guide the formation of the baseline budget and dictate how that budget should be used"); $c f$. Robert D. Reischauer, Framing the Budget Debate for the Future, Testimony Before the Senate Budget Committee 3 (Jan. 29, 2002) (statement on file with authors) ("Rarely have the policies underlying the baseline projections been as disconnected from the policy makers' agendas as they are today.").

${ }^{19}$ Even before the 2001 Act, the CBO projected a long-term fiscal gap of $0.8 \%$ through 2070. See CONG. Budget Office, 107TH Cong., The Long-Term Budget OUTLOOK 9 (2000); see also Alan J. Auerbach \& William G. Gale, Tax Cuts and the Budget, 90 TAX NoTES 1869, 1874 (Mar. 26, 2001) (projecting similar fiscal gap of $0.7 \%$ ).

See Auerbach et al., supra note 18, at 1644-45.

${ }^{21}$ See Cong. Budget Office, 107Th Cong., The Budget and ECONOMIC OUTLOOK: FISCAL YEARS 2002-2011, at 2 tbl.1-1. 
baby boomers reach retirement age and eventually to run short of sufficient funds to pay promised benefits in full. ${ }^{22}$ Nevertheless, since the long-term shortfalls occur beyond the ten-year budget horizon, they are not reflected in the CBO projections. In view of the overwhelming popularity of social security (and the difficulty of implementing structural reform), it would make sense either to take the long-term shortfalls into account or at least to back out the shortterm social security surplus from the ten-year budget projections in order to make a realistic assessment of the affordability of proposed tax cuts. ${ }^{23}$

Another crucial assumption underlying the $\mathrm{CBO}$ projections is that "current laws continue without change." 24 Thus, the law, as it exists at the beginning of the ten-year budget period, is assumed to remain effective and unchanged throughout the period. ${ }^{25}$ The 2001 Act includes several gimmicks designed to exploit this assumption and minimize the revenue loss shown in budget projections. ${ }^{26}$ For example, the Act phases in tax cuts over a nine-year period ${ }^{27}$ and loads a disproportionately large share of the cuts into the later years. ${ }^{28}$ The full cost of the Act becomes apparent only in 2010 when all the cuts

22 See Bd. of Trustees, Federal Old-Age AND Survivors INSURANCE AND DisABILITY INSURANCE TRUST FUNDS, 2002 ANNUAL REPORT 18 (2002) (projecting annual deficits beginning in 2017 and insolvency in 2041).

${ }^{23}$ See Auerbach et al., supra note 18, at 1644-45 (arguing for similar treatment of medicare and other retirement programs).

24 See Cong. Budget Office, 107Th Cong., The Budget and Economic OUTLOOK: FISCAL YEARS 2002-2011, at 5.

25 This assumption, while thoroughly unrealistic, is fully consistent with the purpose of the baseline. See id. at xviii ("CBO does not predict future legislation indeed, any attempt to incorporate future legislative changes in its baseline would undermine the usefulness of those numbers as the base against which to measure the effects of such changes.").

${ }^{26}$ See Gale \& Potter, supra note 4, at 137-38; see also Auerbach et al., supra note 18, at 1645; $c f$. Joel Friedman et al., New Tax-Cut Law Ultimately Costs as Much as Bush Plan: Gimmicks Used to Camouflage \$4.1 Trillion Cost in Second Decade, Ctr. on Budget and Policy Priorities, available at http://www.cbpp.org/5-26-01tax.htm (June 27, 2001) (describing 2001 Act as having "more budget gimmicks than any tax bill - and quite possibly any piece of major legislation - in recent history").

${ }^{27}$ The phase-in period was shortened from ten years to nine years in the conference agreement to bring the final calendar year of tax cuts within the final fiscal year of the ten-year budget period and to avoid running afoul of the Senate's budget rules. See supra note 4.

${ }^{28}$ See Staff of Joint Comm. on TAXation, 107Th Cong., Estimated Budget EFFeCts of THE CONFERENCE AGREEMENT For H.R. 1836 (Joint Comm. Print. 2001); see also Cong. Budget Office, 107Th Cong., The Budget And Economic OUTLOOK: FISCAL YEARS 2003-2012, at 47 tbl.3-2 (2002). 
are fully phased in. Since the estate tax raises a relatively small portion of total federal revenue, ${ }^{29}$ one might expect that estate tax repeal would add little to the cost of the Act. Indeed, projections show relatively modest revenue losses from gradually declining estate tax rates and increasing exemptions during the phase-in period. Losses jump dramatically, however, with complete repeal of the estate tax in $2010 .^{30}$ When all the cuts under the Act are fully phased in, estate tax repeal may account for nearly one-quarter of the annual revenue loss. $^{31}$ After only one year, however, the cuts are scheduled to expire automatically under the sunset provision. Although the CBO projections accept the sunset provision as an unchangeable feature of current law, no one seriously expects the tax cuts to vanish at the stroke of midnight on December 31, 2010. If, as seems likely, the tax cuts are selectively extended or made permanent in modified form, the cost of the Act could be substantially higher for years after 2010.

With each passing year, the ten-year budget horizon moves forward, and the $\mathrm{CBO}$ projections must be updated to take account of developments during the past year. Between January 2001 and January 2002, the fiscal outlook deteriorated dramatically: the projected unified budget surplus for fiscal years 2002-2011 dwindled from $\$ 5.6$ trillion to $\$ 1.6$ trillion. $^{32}$ Of the $\$ 4$ trillion decline, revenue and interest costs of the 2001 Act account for around $\$ 1.7$ trillion,

29 The wealth transfer taxes raised $\$ 29$ billion in 2000 and prior to the 2001 Act were projected to raise $\$ 52$ billion in 2011 , representing around $1.5 \%$ of total federal revenues. See Cong. Budget Office, 107Th Cong., The Budget AND ECONOMIC OUTLOOK: FISCAL YEARS 2002-2011, at 54 tbl.3-2.

${ }^{30}$ The Joint Committee on Taxation projects annual revenue losses (in millions of dollars) from the phase-in and repeal of the estate and generation-skipping transfer taxes during fiscal years 2002-2011 as follows:

\begin{tabular}{|c|c|c|c|c|c|c|c|c|c|c|}
\hline 2002 & 2003 & 2004 & 2005 & 2006 & 2007 & 2008 & 2009 & 2010 & 2011 & Total \\
\hline- & 6,383 & 5,031 & 7,054 & 4,051 & 9,695 & 11,862 & 12,701 & 23,036 & 53,422 & 133,235 \\
\hline
\end{tabular}

See Staff of Joint Comm. ON Taxation, 107Th Cong., Estimated Budget EFFECTS OF THE CONFERENCE AGREEMENT FOR H.R. 1836, at 3.

31 See Len Burman, Treasury's New Distribution Presentation, 90 TAX NoTES 1889, 1889 (Mar. 26, 2001) (noting that, as originally proposed, "estate tax repeal would amount to a $\$ 58$ billion cut in 2011 alone, according to Treasury estimates," representing "nearly one-quarter of the total $\$ 250$ billion tax cut in that year"). This estimate seems plausible under the 2001 Act, but the calculation is complicated by the three-month lag between fiscal and calendar years and by the nine-month lag between a decedent's death and the due date of the estate tax return.

32 See Cong. Budget Office, 107Th Cong., The Budget and Economic OUTLOOK: FISCAL YEARS 2003-2012, at xiv tbl.1. 
economic and technical changes for another $\$ 1.6$ trillion, and increased spending, primarily on defense and homeland security in the wake of the September 11 attacks, for another $\$ 600$ billion. $^{33}$ Excluding the social security surplus, the CBO projections show that costs of the Act exceed available revenues, producing a net deficit of $\$ 700$ billion for fiscal years $2002-2011 .^{34}$ (The projections show annual surpluses at the end of the budget period, but those surpluses are artificially high due to the scheduled termination of the tax cuts at the end of 2010.) However bright the fiscal outlook may have seemed when the tax cuts were first proposed in 2001, the evaporation of the projected ten-year surplus within a single year should prompt even the most zealous abolitionists to reexamine their agenda.

\section{B. Skewed Benefits}

The 2001 Act exacerbates current and long-term fiscal deficits and at the same time provides disproportionate benefits to taxpayers at the very top of the income scale. Proponents of the Act have taken considerable pains to obscure the distributional effects of the tax cuts by focusing exclusively on income tax rate reductions and resorting to unorthodox distributional presentations. Notably, the Treasury Department in March 2001 claimed that the proposed tax cuts would have a distinctly progressive effect and released a distributional analysis purporting to support that claim. ${ }^{35}$

${ }^{33}$ See id. at xiv tbl.1; see also Auerbach et al., supra note 18, at 1641 tbl.2.

${ }^{34}$ The CBO projections for fiscal years $2002-2011$ show a $\$ 742$ billion on-budget deficit and a $\$ 2.343$ trillion off-budget surplus, producing a total surplus of $\$ 1.601$ trillion. See Cong. Budget Office, 107Th Cong., The Budget ANd EConomic OUTLOOK: FISCAL YEARS 2003-2012, at xv tbl.2. These figures reflect a $\$ 1.275$ trillion revenue loss attributable to the 2001 Act. See id. at xiv tbl.1. If the medicare surplus (as well as the social security surplus) is excluded, the total deficit rises to $\$ 1.1$ trillion. See Auerbach et al., supra note 18, at 1640-41.

35 According to the Treasury's press release:

The share of income tax relief provided to families with incomes under $\$ 100,000$ is larger than their share of current income taxes paid ... As a result, these families will pay a smaller share of the total income tax burden under the President's proposal than they do under current law. Conversely, the share of the income tax relief provided to families with incomes of $\$ 100,000$ or more is smaller than their share of current income taxes paid. As a result, these families will pay a larger share of the total income tax burden under the President's proposal than they do under current law.

Press Release, U.S. Dep't of the Treasury, Office of Public Affairs, Treasury Releases Distribution Table for the President's Tax Relief Plan (Mar. 8, 2001). For the accompanying distributional analysis, see Press Release, Office of Tax Analysis, U.S. 
The Treasury analysis, however, is misleading in several material respects. First, it departs from the standard method of classifying households across the income distribution. Instead of using income quintiles, with further differentiation in the top quintile, the Treasury analysis divides households into fixed-dollar income groups, making it difficult to determine how evenly benefits are distributed across the entire set of households. ${ }^{36}$ Second, in presenting the impact of the tax cuts on each income group, the Treasury analysis rejects the standard measure of percentage change in after-tax income, which is widely regarded as "the best measure of the change in a family's wellbeing." ${ }^{37}$ Instead, the Treasury analysis shows each income group's share of the total change in individual income taxes and percentage change in income tax liability, which make the tax cuts for low-income households appear relatively large. ${ }^{38}$ Finally, the Treasury analysis provides data concerning the Act's major income tax provisions but completely ignores the effects of repealing the estate tax while leaving the flat-rate payroll taxes unchanged. ${ }^{39}$ Although the estate tax has not always been included in analyzing the distributional effects of

Dep't of the Treasury, Major Individual Income Tax Provisions of the President's Tax Proposal, available at http://www.ustreas.gov/press/releases/docs/distributionrel.htm (Mar. 8, 2001). For a similar analysis of the 2001 Act, see STAFF OF JoINT COMM. ON TAXATion, 107Th Cong., Distributional EFFects of the Conference AGREEMENT FOR H.R. 1836 (Joint Comm. Print 2001).

${ }^{36}$ See Burman, supra note 31, at 1889-90; see also Julie-Anne Cronin, U.S. Treasury Distributional Analysis Methodology, in 85 OTA PAPERS 34 (1999) (noting that a quintile table conveys a family's relative position in the total income distribution more clearly than a fixed-dollar table, and also facilitates comparisons of tables using different income measures).

${ }^{37}$ Cronin, supra note 36 , at 3; see also Gale \& Potter, supra note 4, at 147 ("A tax cut or increase that gives everyone the same percentage change in take-home income is distributionally neutral - it holds the distribution of after-tax income constant before and after the policy change.").

${ }^{38}$ See Cronin, supra note 36, at 34 (noting that "a given proposal can appear progressive when considering only the total change in tax burdens... or the percentage change in tax burdens ... but regressive when considering the percentage change in after-tax income"). For example, a $\$ 10$ income tax cut for a family with $\$ 10$ of income tax liability shows up as a $100 \%$ reduction, while a $\$ 1,000$ income tax cut for a family with $\$ 10,000$ of income tax liability shows up as a $10 \%$ reduction. See Burman, supra note 31, at 1892.

${ }^{39}$ See Burman, supra note 31, at 1890-91. Repealing the highly progressive estate tax while leaving the flat-rate payroll tax unchanged makes the overall tax system less progressive. See id. at 1891; see also Cronin, supra note 36, at 3 ("An analysis which omitted the payroll tax would yield the incorrect conclusion that the poor, on average, bear no federal tax burden."). 
income tax changes, ${ }^{40}$ the omission seems indefensible in the case of a proposal to repeal the estate tax entirely, especially given the proposal's disproportionate benefit for households at the top of the income distribution. Such a tendentious presentation reveals more about the tactics of the Act's proponents than about the distributional effects of the tax cuts. ${ }^{41}$

A more complete analysis, using standard assumptions and taking the full range of income, estate, and payroll taxes into account, indicates that the Act (when fully phased in) "raises after-tax income by 6.3 percent for households in the top 1 percent of the income distribution, compared to 2.8 percent or less for other groups and less than 1 percent for the bottom quintile," thereby exacerbating inequalities in the distribution of after-tax income. ${ }^{42}$ Moreover, estate tax repeal in 2010 may account for more than one-third of the tax cuts for the top $1 \%$ of the income distribution. ${ }^{43}$

Repeal of the estate tax has a substantial impact on the distribution of tax benefits under the 2001 Act. The estate tax burden

${ }^{40}$ This may be due to uncertainty concerning whether the burden of the estate tax falls on the transferor or the recipient. See, e.g., STAFF OF JOINT COMM. ON TAXation, 107Th CONG., Distributional EFFects OF THE CONFEREnCE AGREEMENT FOR H.R. 1836, at 1-6 (presenting distributional effects of the 2001 Act and noting that "estate and gift taxes are not included due to uncertainty concerning the incidence of these taxes"). The Treasury Department added estate and gift taxes to its distributional analyses in 1998, employing the assumption that the burden is borne by transferors. See Cronin, supra note 36 , at 32 . In any event, the question of incidence should make little difference for distributional analysis to the extent that transferors and recipients have comparable family income. See id.; see also William G. Gale \& Joel B. Slemrod, A Matter of Life and Death: Reassessing the Estate and Gift Tax, 88 TAX Notes 927, 930 (Aug. 14, 2000) (noting that controversy over incidence should not significantly affect the implications for progressivity, since "recipients of estates tend to have very high income and wealth themselves").

41 This characterization is not intended to cast any doubt on the accuracy of the data or the integrity of the "nonpartisan professional staff" in the Office of Tax Analysis who compiled them. Burman, supra note 31, at 1889; $c f$. Martin A. Sullivan, How to Read Tax Distribution Tables, 90 TAx Notes 1747, 1754 (March 26, 2001) (describing the Treasury table as "nothing more than low-grade campaign propaganda reproduced on Treasury letterhead").

${ }^{42}$ Gale \& Potter, supra note 4, at 147 . Alternative measures reveal a similarly skewed distribution of benefits. See id. (noting that top $1 \%$ of income distribution receives $36.7 \%$ of the total tax reduction and a decrease in federal tax liability of more than $11 \%$ ).

${ }^{43}$ See id. ("Both the income and estate tax contribute significantly to benefits for the top 1 percent [of the income distribution]. Estate tax repeal raises after-tax income by 2.3 percent, while the income tax cuts raise after-tax income by 4 percent, more than the total tax cut for any other group."). 
is heavily concentrated in the top $1 \%$ of the income distribution, ${ }^{44}$ making it "the most progressive tax instrument currently at the federal government's disposal." ${ }^{45}$ It follows, therefore, that estate tax repeal will benefit households at the top of the income distribution and correspondingly skew the distribution of benefits under the Act. Furthermore, the growing concentration of pre-tax income and wealth over the past twenty years may suggest a need for more rather than less progressivity in the tax system. ${ }^{46}$ From a broader perspective, the distributional effects of repealing the estate tax will ultimately depend on a host of tax and spending policies that may shift costs from the rich to the poor (e.g., by cutting social programs that benefit primarily low-income families) or from current generations to future generations (e.g., by incurring long-term debt to finance current spending). ${ }^{47}$ As the budget outlook deteriorates and the distributional effects of the Act become clearer, it is time to consider alternatives to permanent repeal of the estate tax.

\section{Alternatives}

The 2001 Act does not simply repeal the estate tax, for such a measure would open a "gaping loophole" in the income tax in the form of an unlimited deathtime basis step-up for appreciated property. ${ }^{48}$ One possible response would be to repeal the basis stepup allowed under current law and extend the income tax to reach unrealized gains at death. A deathtime gains tax would be imposed at lower rates and on a smaller base than the current estate tax;

44 One recent study estimates the distribution of federal estate and income taxes as follows:

\begin{tabular}{|l|r|r|}
\hline & Estate and gift taxes & Individual income tax \\
\hline Top $20 \%$ & $99.2 \%$ & $76.6 \%$ \\
\hline Top $10 \%$ & $96.2 \%$ & $61.3 \%$ \\
\hline Top $5 \%$ & $91.0 \%$ & $49.1 \%$ \\
\hline Top $1 \%$ & $64.2 \%$ & $29.5 \%$ \\
\hline
\end{tabular}

See Cronin, supra note 36, at 24 tbl.12.

${ }^{45}$ William G. Gale \& Joel Slemrod, Rhetoric and Economics in the Estate Tax Debate, 54 NAT'L TAX J. 613, 616 (2001).

${ }^{46}$ See Gale \& Slemrod, supra note 7, at 29.

${ }^{47}$ See Gale \& Potter, supra note 4, at 143-45, 164-66 (discussing possible effects of tax cuts on government expenditures); see also C. Eugene Steuerle, The 2001 Tax Legislation from a Long-Term Perspective, 54 NAT'L TAX J. 427, 429-31 (2001).

${ }^{48}$ Gale \& Slemrod, supra note 7, at 55. 
therefore, such a tax would produce considerably less revenue. ${ }^{49}$ Also, in the absence of large exemptions, which would reduce revenue even further, a deathtime gains tax would likely be substantially less progressive than the current estate tax. ${ }^{50}$ Though seriously proposed and extensively discussed, ${ }^{51}$ a deathtime gains tax has generated no political support in Congress.

Instead, the 2001 Act replaces the estate tax with a new carryover basis regime for inherited property. Revenue estimates for any carryover basis regime depend crucially on the timing of gain realizations, which in turn is extremely uncertain. Even a watertight carryover basis regime would raise significantly less revenue than a deathtime gains tax because it would permit indefinite deferral of gain for beneficiaries who could afford to postpone selling inherited property. $^{52}$ Furthermore, the carryover basis provisions of the Act, laden with large exemptions, will probably raise negligible amounts of revenue and make only a token contribution to the progressivity of the overall tax system.

49 A generic deathtime gains tax might raise around $20 \%$ to $25 \%$ as much revenue as the current estate tax. See CONG. Budget OfFICE, 107TH Cong., Budget OPTIONS 421 (2001) (estimating revenue from deathtime gains tax of $\$ 43.4$ billion for 2002-2006 and \$86.4 billion for 2002-2011); CONG. Budget OfFICE, 107TH Cong., The Budget AND ECONOMIC OUTLOOK: FisCAL YeARS 2002-2011, at 66 tbl.3-11 (2001) (projecting estate and gift tax revenue of $\$ 174$ billion for 2002-2006 and $\$ 402$ billion for 2002-2011).

${ }^{50}$ A recent study suggests that a deathtime gains tax with exemptions for marital bequests and $\$ 250,000$ of gain on a principal residence would produce a lower tax liability than the current estate tax for $95 \%$ of decedents with a net worth of more than $\$ 1,000,000$, but would leave the tax liability roughly unchanged for decedents with a net worth of $\$ 1,000,000$ or less who would otherwise be subject to estate tax. See James M. Poterba \& Scott Weisbenner, The Distributional Burden of Taxing Estates and Unrealized Capital Gains at Death, in RETHINKING ESTATE AND GIFT TAXATION 422, 447-48 (William G. Gale et al. eds., 2001).

${ }^{51}$ See generally U.S. DEP'T OF THE TREASURY, 91st CONG., TAX REFORM Studies AND Proposals 331-51 (Comm. Print 1969); Michael J. Graetz, Taxation of Unrealized Gains at Death: An Evaluation of the Current Proposals, 59 VA. L. REv. 830 (1973); Zelenak, supra note 9; Burke \& McCouch, supra note 10.

${ }^{52}$ A generic carryover basis regime might raise around $7 \%$ to $13 \%$ as much revenue as the current estate tax. See CONG. Budget OfFICE, 107TH CONG., Budget OPTIONS 422 (2001) (estimating revenue from carryover basis of $\$ 11.5$ billion for 2002-2006 and \$52.5 billion for 2002-2011); CONG. Budget OfFICE, 107TH Cong., The Budget AND ECONomic OUTLOOK: Fiscal Years 2002-2011, at 66 tbl.3-11 (2001) (projecting estate and gift tax revenue of $\$ 174$ billion for 2002-2006 and $\$ 402$ billion for 2002-2011).

53 See Gale \& Slemrod, supra note 7, at 56 (noting that revenue from carryover basis with generous exemptions would be "significantly smaller" than under CBO 
An obvious alternative to permanent repeal is to retain the estate tax with larger exemptions, a broader base, and lower rates than currently exist. $^{54}$ In fact, this approach was proposed in the House during consideration of the 2001 Act, $^{55}$ and has subsequently been offered as a possible solution to the impasse over the Act's sunset provision. $^{56}$ While precise levels of rates and exemptions are inevitably subject to negotiation and compromise in the legislative process, it seems clear that with a few incremental adjustments, the current estate tax could be scaled back to reach a very small number of extremely large estates at a relatively modest sacrifice of revenue. Recent data on estate tax returns filed in 2000 are revealing in this respect. Of the 52,000 taxable estate tax returns filed in that year, those showing gross estates of $\$ 5,000,000$ or more - the top $7 \%$ reported more than half of the total estate tax, and those showing gross estates of $\$ 2,500,000$ or more - the top $18 \%$ - reported nearly three-quarters of the total estate tax. ${ }^{57}$ Thus, raising the estate tax

projections); Leonard Burman, Comment, in RETHINKING EsTATE AND GIFT TAXATION 450, 455 (William G. Gale et al. eds., 2001) (noting that a carryover basis regime with large exclusions "could actually discourage realization of capital gains costing individual income tax revenue as well as estate taxes"). In the absence of wealth transfer taxes, a carryover basis regime could also lead to widespread income tax avoidance. See Jonathan G. Blattmachr \& Mitchell M. Gans, Wealth Transfer Tax Repeal: Some Thoughts on Policy and Planning, 54 NAT'L TAX J. 569, 574-76 (2001).

${ }^{54}$ For a thoughtful discussion of additional estate tax reforms, see William J. Turnier, Three Equitable Taxpayer-Friendly Reforms of Estate and Gift Taxation, 87 TAX NotEs 269 (Apr. 10, 2000).

55 See H.R. REP. No. 107-37, at 194 (2001) (setting forth dissenting views of Democratic members of House Ways and Means Committee and proposing immediate increases in estate tax exemption).

${ }^{56}$ See H.R. 5008, 107th Cong. (2002) (proposing retention of wealth transfer taxes with $\$ 3,500,000$ exemption and $50 \%$ top marginal rate).

${ }^{57}$ A recent study of federal estate tax returns shows the following categories of taxable returns and the reported net estate tax liability for 2000 :

\begin{tabular}{|l|r|r|}
\hline Size of gross estate & Number of taxable returns & Net estate tax $(\$ 000)$ \\
\hline$\$ 600,000$ up to $\$ 1,000,000$ & 18,634 & 769,024 \\
\hline$\$ 1,000,000$ up to $\$ 2,500,000$ & 23,827 & $5,485,892$ \\
\hline$\$ 2,500,000$ up to $\$ 5,000,000$ & 5,917 & $5,081,333$ \\
\hline$\$ 5,000,000$ up to $\$ 10,000,000$ & 2,258 & $4,405,023$ \\
\hline$\$ 10,000,000$ up to $\$ 20,000,000$ & 814 & $2,937,499$ \\
\hline$\$ 20,000,000$ or more & 549 & $5,719,851$ \\
\hline Total & 52,000 & $24,398,622$ \\
\hline
\end{tabular}

See Barry W. Johnson \& Jacob M. Mikow, Federal Estate Tax Returns, 1998-2000, 21 STAT. INCOME BULl. 133, 168 tbl.1c (2002). 
exemption to $\$ 5,000,000$ would have eliminated estate tax liability for all but the wealthiest 3621 decedents $-0.0015 \%$ of total deaths ${ }^{58}$ while preserving more than half the revenue generated by the current estate tax.

By targeting the estate tax at extremely large accumulations of inherited wealth, ${ }^{59}$ such a proposal could quickly erode political support for outright repeal. Perhaps for that very reason, opponents of the estate tax have steadfastly pursued the goal of abolishing the tax rather than reforming it. As the effects of the 2001 Act become clearer during the extended phase-in period, a central issue to which we now turn our attention is whether the Act's new carryover basis regime represents a viable replacement for the estate tax.

\section{CARRYOVER BASIS: ILLUSIONS AND REALITIES}

On its face, the 2001 Act announces carryover basis as the general rule for property acquired from a decedent after $2009 .^{60}$ Yet this description is misleading, or at least incomplete, in several respects. As already noted, the new carryover basis regime is scheduled to come into force in 2010 and then to expire one year later due to the sunset provision. ${ }^{61}$ In some quarters, the sunset provision may be viewed simply as a procedural quirk, a political compromise, or a device to disguise the long-term cost of estate tax repeal. Nevertheless, any serious assessment of the Act's carryover basis provisions must start by assuming that those provisions might actually take effect and remain in force indefinitely. Accordingly, for purposes

58 See Arialdi M. Minino \& Betty L. Smith, Deaths: Preliminary Data for 2000 , 49 NAT'L Vital Statistics Report No. 12, at 3 tbl.A (Oct. 9, 2001) (showing $2,391,399$ total United States deaths in 1999). Under current law, the 52,000 taxable estate tax returns filed in 2000 represented around $2 \%$ of total deaths in the preceding year. See supra note 57.

59 See Gale \& Slemrod, supra note 7, at 22-23 (noting need for more empirical work on motives and patterns of bequests of the very wealthy, in analyzing role of estate tax).

${ }^{60}$ See I.R.C. $§ 1022$ (a) (providing for basis equal to lesser of decedent's adjusted basis or fair market value at death). Technically the carryover basis rules of section 1022 apply only to "property acquired from a decedent," which includes (1) "property acquired by bequest, devise, or inheritance, or by the decedent's estate from the decedent;" (2) property transferred by the decedent during life to a "qualified revocable trust," or to any other trust subject to a reserved power to alter, amend, or terminate; and (3) property passing from the decedent by reason of death without consideration. See I.R.C. $\$ 1022(\mathrm{e})$. The rules do not apply to items of income in respect of a decedent. See I.R.C. § 1022(f).

${ }^{61}$ See supra note 4. 
of the present discussion, we disregard the sunset provision and focus on the impact of the new carryover basis regime.

\section{A. Disappearing Gain}

Perhaps the most striking feature of the new regime is its narrow field of application. The vast bulk of property passing from decedents each year will continue to receive a fresh basis equal to its deathtime fair market value, as under current law. ${ }^{62}$ The carryover basis provisions added by the 2001 Act will govern only a tiny fraction of this property. This is due primarily to two large exemptions that authorize a tax-free basis step-up for appreciated property ${ }^{63}$ owned by the decedent at death. ${ }^{64}$ The first exemption allows a basis increase for up to $\$ 1,300,000^{65}$ of unrealized appreciation in any property owned at death. The second exemption allows a separate, additional basis increase for up to $\$ 3,000,000$ of unrealized appreciation in property passing to the decedent's surviving spouse in qualifying form. ${ }^{66}$ The dollar amount of each exemption is indexed for inflation

${ }^{62}$ Cf. I.R.C. \$ 1014(a)(1) (providing basis equal to fair market value at death).

${ }^{63}$ In the case of property with a basis greater than its fair market value at death, basis is automatically stepped down to fair market value. See I.R.C. §1022(a). Certain losses that are not allowed as deductions on the decedent's final return may nevertheless be used to increase the basis of appreciated property. See I.R.C. $\S 1022(b)(2)(C)$.

${ }^{64}$ See I.R.C. $\$ 1022$ (b)-(d). Property "owned by the decedent at the time of death" (and hence potentially eligible for a basis step-up) includes (1) a portion of property held by the decedent and another person as joint tenants with right of survivorship (or tenants by the entirety), (2) property transferred by the decedent during life to a "qualified revocable trust," and (3) the one-half share of community property held by the decedent and a surviving spouse. See I.R.C. $\S 1022(\mathrm{~d})(1)(\mathrm{A})$ (B). The decedent is not treated as owning property merely by virtue of a power of appointment. See I.R.C. $\S 1022$ (d)(1)(B)(iii). The basis step-up is also unavailable for certain property acquired by gift within three years of death and for interests in certain foreign entities. See I.R.C. $\$ 1022$ (d)(1)(C)-(D).

${ }^{65}$ See I.R.C. $\$ 1022$ (b). The $\$ 1,300,000$ amount is increased by any unused capital loss carryovers, net operating loss carryovers, and built-in section 165 losses. See I.R.C. $\S 1022(b)(2)$ (C). It is unclear whether this adjustment is taken into account before making the inflation adjustment under section 1022(d)(4). See infra note 67 and accompanying text.

${ }^{66}$ See I.R.C. $\$ 1022(\mathrm{c})$. Property eligible for the spousal exemption, defined as "qualified spousal property," is essentially the same as (1) property qualifying for the estate tax marital deduction under current law, including the terminable interest rule ("outright transfer property"), and (2) qualified terminable interest property (QTIP). See I.R.C. § 1022(c)(3)-(5); cf. I.R.C. \$ 2056(a), (b)(1), (b)(3), (b)(7). 
after $2010,{ }^{67}$ though obviously the inflation adjustment can take effect only if the sunset provision is repealed. Both exemptions are elective; the decedent's executor has broad discretion to allocate the allowable basis increase to eligible property, but no allocation can increase the basis of property above its deathtime fair market value. ${ }^{68}$

As a conceptual matter, it might be argued that any tax-free basis increase at death violates the integrity of the income tax and should not be tolerated. ${ }^{69}$ As a practical matter, however, some sort of limited basis step-up seems unavoidable. To require that taxpayers identify and report every dollar of unrealized gain in estates of small or moderate size would be unreasonably burdensome and hopelessly unenforceable. The exemptions in the 2001 Act, however, go far beyond the exigencies of practical administration. For example, the amount of the $\$ 1,300,000$ general exemption corresponds to the aggregate value of property that is sheltered from estate tax by the unified credit and the deduction for family-owned business interests under current law. ${ }^{70}$

At first glance, it may seem reasonable to set the amount of the deathtime basis step-up equal to the estate tax exemption, for this makes it possible to claim that the new regime will not impose a tax burden on taxpayers who were previously exempt from estate tax. Such a claim may have rhetorical appeal, but it is inaccurate and misleading. Although by and large the 2001 Act reduces taxes on deathtime transfers, it is not difficult to imagine a situation in which the new regime produces a heavier tax burden than current law. For example, suppose a decedent dies leaving property with a fair market value of $\$ 2,000,000$ and a basis of $\$ 50,000$, encumbered by liabilities of $\$ 1,500,000$. Under current law, the transfer is free of estate tax because the net value falls within the estate tax exemption, ${ }^{71}$ and the

${ }^{67}$ See I.R.C. § 1022(d)(4).

${ }^{68}$ See I.R.C. $\$ 1022$ (d)(2).

${ }^{69}$ See Joseph M. Dodge, What's Wrong With Carryover Basis Under H.R. 8, 91 TAX Notes 961, 963-64 (May 7, 2001).

${ }^{70}$ Prior to the $2001 \mathrm{Act}$, the unified credit and the deduction for "qualified family-owned business interests" allowed up to $\$ 1,300,000$ of deathtime transfers to pass free of estate tax. See I.R.C. $\S \S 2010$ (c), 2057(a)(3). The $\$ 1,300,000$ amount also appeared in an earlier carryover basis bill approved by Congress but vetoed by President Clinton in 2000. See Death Tax Elimination Act of 2000, H.R. 8, 106th Cong. $\S 103$ (proposing exemption for property with an "adjusted fair market value" of $\$ 1,300,000)$.

71 The taxable estate (net of the $\$ 1,500,000$ liability) is $\$ 500,000$, which generates an estate tax of $\$ 155,800$. Assuming the decedent made no other taxable transfers, the estate tax is fully offset by an equal amount of the unified credit. See I.R.C. 
recipient takes the property with a stepped-up basis of $\$ 2,000,000 .^{72}$ In contrast, under the new regime, after a basis increase of $\$ 1,300,000$, the recipient takes the property with a basis of $\$ 1,350,000$. The transfer, of course, remains free of estate tax, but if the recipient sells the property, the resulting gain of $\$ 650,000$ will probably be taxed at a $20 \%$ rate, generating a capital gain of $\$ 130,000$.

Such outcomes, of course, are relatively rare. For the vast majority of estates that already receive a full tax-free basis step-up at death, the 2001 Act will make little or no difference because any unrealized appreciation will likely be eliminated by one or more exemptions from carryover basis. But this merely leads back to more fundamental questions concerning the size and structure of those exemptions. Linking the size of the income tax and estate tax exemptions may be sensible in a system where each tax complements the other. ${ }^{73}$ With the repeal of the estate tax, however, the estate tax exemption no longer has special relevance as a benchmark of administrative convenience for a tax-free basis increase at death. The $\$ 1,300,000$ amount - a figure already superseded by increases in the estate tax exemption under the $2001 \mathrm{Act}^{74}$ - seems demonstrably arbitrary. The $\$ 1,300,000$ general exemption, together with the $\$ 3,000,000$ spousal exemption, will not merely preserve but substantially expand the amount of property receiving a tax-free basis step-up at death. This is arguably a step in precisely the wrong direction, for it exacerbates the revenue costs of repealing the estate tax and heedlessly squanders an opportunity to redress a glaring defect in the income tax. ${ }^{75}$

The structure of the exemptions also deserves closer scrutiny. The $\$ 1,300,000$ general exemption and the $\$ 3,000,000$ spousal exemption provide basis increases by, not to, the specified dollar amounts and accordingly apply without regard to the size of the estate or the value of the property involved. ${ }^{76}$ This approach stands in

$\S \S 2001(\mathrm{a})-(\mathrm{c}), 2010,2051,2053(\mathrm{a})(3)$.

${ }^{2}$ See I.R.C. § 1014(a).

73 For example, when the 1976 Act introduced carryover basis as a complement to the newly unified gift and estate tax system, there were plausible reasons to coordinate the income tax and estate tax provisions concerning identification and valuation of property transferred at death. Thus, the tax-free basis step-up at death was set equal to the $\$ 60,000$ estate tax exemption then in effect. See former I.R.C $\S$ $1023(\mathrm{~d})(1)$.

74 The estate tax exemption is scheduled to rise from $\$ 1,000,000$ in 2002 to $\$ 3,500,000$ in 2009. See I.R.C. $\$ 2010$ (c).

${ }^{75}$ See supra note 48 and accompanying text.

${ }^{76}$ An alternative form of exemption would apply to property up to a specified 
marked contrast to the "minimum basis" approach adopted in the 1976 legislation, which allowed a basis increase only to the extent that the specified amount exceeded the decedent's total basis in all property owned at death. The main advantage of the minimum basis approach stems from its inherent self-adjusting feature: the basis increase vanishes if the decedent's total basis equals or exceeds the specified amount, ${ }^{77}$ making it possible to target the benefit of the exemption at small or moderate estates. In rejecting this approach, the 2001 Act misses yet another opportunity to contain the revenue costs of estate tax repeal.

Under the 2001 Act, with a bit of elementary planning, a married couple can make up to $\$ 5,600,000$ of unrealized appreciation disappear from the income tax base: $\$ 4,300,000$ at the death of the first spouse (assuming optimal use of the spousal exemption), and another $\$ 1,300,000$ at the death of the surviving spouse. Note well that these amounts refer to unrealized appreciation, not fair market value. Given the size and composition of decedents' estates, the benefit of the exemptions appears to be systematically skewed in favor of taxpayers at the very top of the wealth distribution. In general, the ratio of unrealized appreciation to the total value of property owned at death tends to rise with net worth. $^{78}$ Leaving aside personal residences, which enjoy a separate gain exclusion under the Act, ${ }^{79}$ the pattern is even more pronounced. ${ }^{80}$

Predictably, only a tiny fraction of decedents leave property with

value. Cf. Death Tax Elimination Act of 2000, H.R. 8, 106th Cong. $§ 103$ (providing basis increase for property with an "adjusted fair market value" (i.e., net of secured indebtedness) of $\$ 1,300,000$ ).

77 See Burke \& McCouch, supra note 10, at 529-31 (discussing minimum basis approach adopted in $1976 \mathrm{Act}$ ).

78 According to one study, based on the 1998 Survey of Consumer Finances, unrealized capital gains at death represent $36 \%$ of the total expected value of all estates and $56 \%$ of the total expected value of estates of $\$ 10,000,000$ or more. See Poterba \& Weisbenner, supra note 50, at 439, 440 tbl.10-8.

79 Unrealized gain on a principal residence that is owned at death and subsequently sold by the recipient will be eligible for the $\$ 250,000$ gain exclusion under section 121, as amended by the 2001 Act. See I.R.C. $\$ 121(d)(9)$.

${ }^{80}$ A recent study indicates that primary residences account for more than $90 \%$ of unrealized appreciation in households with net worth below $\$ 500,000$, and less than $4 \%$ in households with net worth of $\$ 10,000,000$ or more. See Poterba \& Weisbenner, supra note 50, at 439 . If those data are adjusted to exclude primary residences, unrealized appreciation accounts for around $4 \%$ of total value in households with net worth below $\$ 500,000$, around $27 \%$ of value in households with net worth from $\$ 1,000,000$ to $\$ 5,000,000$, and around $56 \%$ of value in households with net worth of $\$ 10,000,000$ or more. Cf. id. at 440 tbl.10-8. 
sufficient unrealized appreciation to make full use of the available basis increases. For example, a decedent with a net worth of $\$ 2,000,000$ is likely, on average, to have unrealized appreciation of around $\$ 700,000$ - an amount that does not even approach the ceiling on tax-free basis step-ups under the new regime. ${ }^{81}$ Suppose instead that a decedent with a net worth of $\$ 10,000,000$, including $\$ 5,600,000$ of unrealized appreciation, leaves all the property to a surviving spouse, who dies soon afterward leaving the property to their children. $^{82}$ In this case, the $\$ 4,300,000$ basis increase at the first spouse's death, combined with the $\$ 1,300,000$ basis increase at the surviving spouse's death, are just sufficient to exhaust the available exemptions and to eliminate the unrealized gain without triggering carryover basis treatment. Clearly, given the size and structure of the exemptions, the vast majority of property transferred at death will receive a tax-free basis step-up, and the carryover basis provisions of the 2001 Act will apply primarily to a small number of very large estates. Ironically, the taxpayers at the pinnacle of the wealth distribution are best situated to defer realizing gains indefinitely, thereby reducing the effective rate of capital gains tax to a negligible level. ${ }^{83}$ For large accumulations of dynastic wealth that can be passed on intact for several generations, carryover basis may prove to be little more than an illusion.

\section{B. Rewards of Marriage}

The $\$ 3,000,000$ spousal exemption, which dwarfs the general exemption in size, is especially troublesome because it lacks any convincing policy justification and raises serious issues of fairness. ${ }^{84}$ Under a carryover basis regime, there is generally no need for a separate spousal exemption, since appreciated property passing from

${ }^{81}$ See id. at 440 tbl.10-8 (showing $34.63 \%$ appreciation-to-value ratio, on average, for estates between $\$ 1,000,000$ and $\$ 5,000,000)$.

${ }^{82}$ See id. at 439 (noting that unrealized appreciation represents $56 \%$ of value of estates worth $\$ 10,000,000$ or more). The example in text assumes that the property passing to the surviving spouse has at least $\$ 3,000,000$ of unrealized appreciation.

83 In effect, deferring the realization of built-in gain is equivalent to reducing the effective tax rate. See Cong. Budget Office, 105Th Cong., Perspectives on the OWNership of Capital Assets and the Realization of Capital Gains 10-11 (1997) (noting that "the effective tax rate on an asset that appreciates in value at 7 percent per year would be about one-half the statutory rate of 28 percent if the asset was held for 30 years").

${ }^{84}$ See Dodge, supra note 69, at 966 (describing spousal exemption as "contrary to any discernable logic or policy"). 
a decedent to a surviving spouse is not subject to a deathtime tax in any event. In the absence of hardship, no special basis increase should be allowed for property passing to the spouse. ${ }^{85}$ Indeed, it seems anomalous to allow a special basis increase for property passing to a surviving spouse at death, while imposing a strict carryover basis on property passing to the spouse by gift during life. ${ }^{86}$ The most plausible explanation for the spousal exemption in the 2001 Act is simply that it perpetuates a preexisting advantage of spousal bequests. Under current law, property passing from a decedent to a surviving spouse (in qualifying form) escapes the estate tax by virtue of the marital deduction, yet it automatically receives a tax-free basis step-up. ${ }^{87}$ In a similar vein, the 2001 Act preserves the peculiar preference for community property under current law, ${ }^{88}$ which allows a tax-free basis step-up for both halves of the property at the death of the first spouse, even though only half of the value of the property is includible in the decedent's gross estate. ${ }^{89}$ Explaining the origins of these anomalies in current law, however, does not justify their continuation under the new regime.

The spousal exemption accentuates two objectionable features of

${ }^{85}$ For example, the 1976 Act provided no special spousal exemption, but did allow a basis adjustment for estate tax attributable to unrealized appreciation in property subject to estate tax. See former I.R.C. $\S 1023(\mathrm{c})$. This adjustment was intended to prevent pre-death appreciation from being subject both to an estate tax at death and an income tax at the time of a subsequent sale. No adjustment was necessary, however, with respect to property qualifying for a marital or charitable deduction, since such property was not "subject to [estate] tax." See former I.R.C. $\S 1023(f)(4)$. With the repeal of the estate tax, the need for the adjustment also disappears.

${ }^{86}$ See I.R.C. $\$ 1041$. Lifetime gifts to a spouse ordinarily escape gift tax by virtue of the marital deduction. See I.R.C. $\$ 2523(\mathrm{a})$.

87 See I.R.C. $\$ \$ 1014(\mathrm{a}), 2056$.

${ }^{88}$ The 2001 Act treats the surviving spouse's interest in community property as "owned by, and acquired from, the decedent" and hence potentially eligible for an elective basis step-up. See I.R.C. $\$ 1022$ (d)(1)(B)(iv).

${ }^{89}$ See I.R.C. $\$ 1014(\mathrm{~b})(6)$. See generally BORIS I. BITTKER \& LAWRENCE LoKken, Federal TAXATION OF INCOME, Estates AND GifTS II 41.4.4, at 41-42 to 41-43 (3d ed. 2000).

${ }^{90}$ One commentator argues that a properly designed carryover basis regime could "level the playing field and generally extend uniform tax treatment to gifts and bequests, spousal bequests and bequests to children, gains realized during life and those held at death, and deaths in community property versus non-community property states." See David Joulfaian, Choosing Between an Income Tax and a Wealth Transfer Tax, 54 NAT'L TAX J. 629, 642 (2001). The $\$ 3,000,000$ spousal exemption and the continued preference for community property, however, ensure that the 2001 Act will not achieve these "tax harmony objectives." Id. 
current law concerning qualified terminable interest property (QTIP). First, in order to be eligible for a basis increase, a transfer must qualify either as "outright transfer property" meeting the convoluted requirements of the terminable interest rule or as QTIP." In effect, by retaining QTIP as the only viable alternative to an outright transfer, the 2001 Act encourages testators to provide the minimum qualifying interest - a life estate - for their surviving spouses while retaining full control over the ultimate disposition of the underlying property. Indeed, the spousal exemption is available for an accumulation trust for the sole benefit of the spouse or his or her estate (which qualifies, ironically, as "outright transfer property") but not for the traditional combination of a life estate with a presently exercisable general power of appointment. ${ }^{92}$ Given the statistical gender disparities in wealth and life expectancy (on average, husbands are both wealthier and shorter-lived than wives), it comes as no surprise that some perceive the QTIP provisions as a symbol of deeprooted gender inequality. ${ }^{93}$ At the same time, the large size of the spousal exemption may encourage testators to leave more property to their spouses at death (albeit in QTIP form) than they would do in the absence of such a powerful tax incentive. ${ }^{94}$ The second problem with a spousal exemption for QTIP is that the basis increase will most likely benefit the remainder takers rather than the spouse. If the spouse receives only a life estate, there is no assurance that the underlying property will be sold during the spouse's life. ${ }^{95}$ In effect, the QTIP provisions may be viewed as promoting marriage as a sort of tax

${ }^{91}$ See I.R.C. $\$ 1022(\mathrm{c})(3)$.

92 As a technical matter, the accumulation trust complies with the terminable interest rule, but the life estate coupled with a presently exercisable general power of appointment violates both the terminable interest rule and the QTIP requirements.

${ }^{93}$ See Wendy C. Gerzog, The Marital Deduction QTIP Provisions: Illogical and Degrading to Women, 5 UCLA WOMEN's L.J. 301 (1995); see also Mary Louise Fellows, Wills and Trusts: "The Kingdom of the Fathers", 10 L. \& INEQ. 137, 156-59 (1991). For a different perspective, see Lawrence Zelenak, Taking Critical Tax Theory Seriously, 76 N.C. L. REV. 1521, 1542-49 (1998); see also Wendy C. Gerzog, The Illogical and Sexist QTIP Provisions: I Just Can't Say It Ain't So, 76 N.C. L. REV. 1597 (1998); Joseph M. Dodge, A Feminist Perspective on the QTIP Trust and the Unlimited Marital Deduction, 76 N.C. L. REV. 1729 (1998).

94 The unlimited estate tax marital deduction creates a similar incentive under current law. Accordingly, estate planners routinely draft formula marital bequests designed to reduce the estate tax to zero at the death of the first spouse.

${ }^{95}$ Even if a sale occurs, any gain (including the tax savings from the basis increase) will ordinarily be allocated to principal rather than income. The spouse will benefit only indirectly, to the extent that the sale proceeds are reinvested in higheryielding assets. See Dodge, supra note 69, at 966. 
shelter for the benefit of those who receive property after the death of the surviving spouse. ${ }^{96}$

Even in the case of an outright bequest, the benefit of the spousal exemption may be shifted to other beneficiaries through the creative use of liabilities. If a decedent leaves encumbered property, any liabilities in excess of basis are generally disregarded in determining whether the decedent (or the estate) recognizes gain and in determining the recipient's basis. ${ }^{97}$ This rule prevents the excess liabilities from triggering an immediate income tax at death, and leaves the recipient with a carryover basis in the encumbered property. ${ }^{98}$ By its terms, however, the rule does not prevent a basis increase for encumbered property passing to the decedent's surviving spouse, even though the spouse may end up bearing the burden of liabilities incurred for the benefit of other beneficiaries. For example, suppose $H$ is married to $W$ and wishes to leave $\$ 5,000,000$ to their child $C$. $H$ owns property with a fair market value of $\$ 5,000,000$ and a basis of $\$ 700,000$, but $H$ does not leave the property directly to $C$. Instead, he borrows $\$ 5,000,000$ secured by the property and then leaves the cash proceeds to $C$ and the property to $W$. At $H$ 's death, the property passing to $W$ is eligible for a total basis increase of $\$ 4,300,000$ (i.e., a $\$ 1,300,000$ general exemption and a $\$ 3,000,000$ spousal exemption), thereby eliminating all of the built-in gain. $W$ will eventually bear the burden of repaying the $\$ 5,000,000$ liability, leaving her with a net benefit of zero, while $C$ receives a tax-free bequest of $\$ 5,000,000$. As a result, the benefit of the spousal exemption is in effect shifted to $C$.

Married couples also enjoy a special exemption from the antiabuse provisions concerning deathbed gifts. In general, the $2001 \mathrm{Act}$ disallows any basis increase at death for property that the decedent received by gift within three years before death. ${ }^{99}$ The evident purpose of the three-year rule is to forestall a gift of appreciated

96 See id. at 967 (criticizing "large exemption from income tax for the collective legatees of wealthy descendents [sic] who happen to have been married at death").

97 See I.R.C. $\$ 1022(\mathrm{~g})$.

98 Suppose $D$, who owns property with a fair market value of $\$ 10,000,000$ and a basis of $\$ 1,000,000$, takes out a $\$ 10,000,000$ loan secured by the property. In an attempt to achieve a full basis step-up, $D$ leaves the borrowed proceeds to a child by will and the encumbered property to charity. To prevent this gambit, the $2001 \mathrm{Act}$ provides that the excess liabilities rule does not apply in the case of a transfer to a "tax-exempt beneficiary." See id. Presumably, $D$ (or $D$ 's estate) must recognize a gain of $\$ 9,000,000$ (less any basis increase allocated by the executor to the encumbered property).

${ }^{99}$ See I.R.C. $\S 1022(\mathrm{~d})(1)(\mathrm{C})$. 
property by a donor to an elderly or terminally ill donee in the expectation of reacquiring the property with a stepped-up basis at the donee's death. $^{100}$ In contrast to its counterpart in current law, ${ }^{101}$ the three-year rule applies even if the property ends up in the hands of a person other than the original holder (or the holder's spouse). Amazingly, however, the three-year rule does not apply to property given to the decedent by the decedent's spouse. ${ }^{102}$ This exception represents an open invitation to spouses to engage in basis-laundering transactions that would be branded as abusive in any other context. For example, if a husband is terminally ill and his wife owns appreciated property, the wife can give the property to her husband and (with the husband's cooperation) receive the property back from him at death with up to $\$ 3,000,000$ of gain laundered out. ${ }^{103}$ On its face, the three-year rule does not allow even a spouse to launder property received by gift from a third person, ${ }^{104}$ but the difficulty of tracing property to its original source may render the three-year rule unenforceable as a practical matter. ${ }^{105}$

\section{An Unlevel Playing Field: Pensions and Life Insurance}

The 2001 Act continues the provisions of current law governing income in respect of a decedent (IRD). Very generally, IRD refers to items of income accrued or to which the decedent became entitled during life but not realized before death for income tax purposes. Common examples include accrued but unpaid salary, interest, or dividends. ${ }^{106}$ By far the most important category of IRD consists of

100 Although by its terms the rule refers only to gifts received within three years of death, it also applies to bequests, since property acquired from a decedent is "treated [for income tax purposes] as transferred by gift." I.R.C. $\S 1022(a)(1)$.

101 See I.R.C. $\$ 1014$ (e) (disallowing basis step-up for property reacquired from decedent by donor who gave property to decedent within one year before death).

102 See I.R.C. § 1022(d)(1)(C)(ii). Nevertheless, the spousal exception does not apply to property that the spouse acquired by gift during the three-year period. This qualification is necessary to prevent the use of the spouse as a conduit to achieve a basis step-up for property originally owned by third persons.

${ }^{103}$ See David R. Hodgman, Carryover Basis: Planning and Drafting Issues, 28 EST. Plan. 611, 613 (2001).

${ }^{104}$ See I.R.C. $\$ 1022(\mathrm{~d})(1)(\mathrm{C})(\mathrm{ii})$.

105 Similar tracing problems arise in determining the source of contributions to property held in joint tenancy. See I.R.C. $\S 1022$ (d)(1)(B)(i)(II). Unlike the current estate tax provisions, the 2001 Act contains no express presumption concerning the source of contributions. Cf. I.R.C. $\$ 2040$ (a).

106 See Treas. Reg. $\$ 1.691(a)-2(b)$ (as amended in 1965). See generally BORIS I. BitTKer \& LAWrence LoKken, Federal TAXation of InCOME, Estates and 
tax-deferred retirement benefits (i.e., qualified pension plans and individual retirement accounts) payable to the decedent's estate or to designated beneficiaries. To prevent bunching of income on the decedent's final return, current law generally requires that the recipient step into the decedent's shoes and include IRD in gross income in the year of receipt. ${ }^{107}$ As a corollary, IRD is ineligible for the deathtime basis step-up allowed for other property. ${ }^{108}$

The 2001 Act expressly carves out all items of IRD from the scope of the new carryover basis regime, ${ }^{109}$ thereby preventing such items from receiving any basis increase and ensuring that they remain subject to the step-in-the-shoes provisions of current law. On one hand, this rigorous approach makes sense as a means of preserving the integrity of the provisions governing distributions of tax-deferred retirement benefits and preventing tax deferral from being converted to tax forgiveness. ${ }^{110}$ On the other hand, the treatment of IRD cannot be explained in terms of the character of the income involved since the Act readily allows basis increases for other types of appreciated property without regard to whether the built-in gain is ordinary or capital. ${ }^{111}$ Arguably, IRD should receive no less favorable treatment than other property. ${ }^{112}$ Nevertheless, under the Act, moderate estates consisting mainly of tax-deferred retirement benefits may be unable to take advantage of the generous basis increases that remain freely available to much larger estates holding other forms of highly appreciated property. ${ }^{113}$

GIFTS II 83.1.2, at 83-3 to 83-8 (2d ed. Supp. 2001).

${ }^{107}$ See I.R.C. $\$ 691(\mathrm{a})(1)$.

${ }^{108}$ See I.R.C. $\$ 1014(\mathrm{c})$.

109 See I.R.C. $\S 1022(f)$. The 1976 Act contained a similar provision. See former I.R.C. $\S 1023(\mathrm{~b})(2)(\mathrm{A})$.

${ }^{110}$ Distributions are generally taxed as ordinary income, even though they may consist in large part of investment yield that would be taxed as capital gain if earned outside a tax-deferred retirement vehicle. See I.R.C. $\$ 72$; see also Gale \& Slemrod, supra note 45 , at 624 (noting "little objection, and certainly no moralistic fervor" concerning treatment of tax-deferred retirement benefits under current law).

111 See infra note 150 and accompanying text (discussing selective allocation). Moreover, while most IRD items represent ordinary income with a basis of zero, this is not always true; some IRD items represent capital gain (e.g., gain from sale of property pending at death).

${ }^{112}$ See Dodge, supra note 69, at 965 (criticizing ineligibility of IRD for basis increase). Alternatively, if it were possible to bifurcate retirement benefits into separate portions representing deferred compensation and investment returns, it might be argued that at least the latter should be eligible for a basis increase.

${ }^{113}$ See Stefan F. Tucker, Thoughts on Radical Estate and Gift Tax Reform, 91 TAX NOTES 163, 167 (Apr. 2, 2001). The relatively disadvantageous treatment of IRD 
In stark contrast to the relatively harsh treatment of IRD, the 2001 Act retains the extraordinarily favorable treatment of life insurance under current law, including the exclusion from the recipient's gross income of life insurance proceeds payable at death. ${ }^{114}$ In effect, this amounts to forgiveness of tax on any mortality gain at death, entirely outside the scope of the carryover basis provisions. As a result, even in the absence of the estate tax, life insurance will retain its entrenched tax-privileged status under the new regime.

\section{IMPLEMENTATION}

At first glance, the concept of carryover basis seems relatively simple and straightforward. Experience under the 1976 Act, however, suggests that the viability of the new carryover basis regime depends crucially on the manner of its implementation. To be sure, the 2001 Act sidesteps some of the problems that arose under the 1976 Act. For example, the repeal of the estate tax removes the need for a special basis adjustment for the estate tax attributable to unrealized appreciation. $^{115}$ In addition, the free allocation of available basis adjustments avoids the complexity of mandatory allocation formulas. $^{116}$ At the same time, however, the 2001 Act conspicuously fails to address important issues of administration and enforcement. Concerns about the workability of the new carryover basis regime will

may also affect asset allocation decisions. Taxpayers will have a tax incentive (as they do under current law) to make low-risk, low-return investments with tax-deferred retirement assets and high-risk, high-return investments with other assets, in order to take advantage of capital gain rates and the deathtime basis step-up for the latter category.

114 See I.R.C. $\S 101$ (a). Furthermore, the inside investment build-up during the insured person's life is exempt from tax.

115 Although the 1976 Act allowed basis adjustments for state death taxes attributable to unrealized appreciation in the estate, see former I.R.C. $\$ 1023$ (c), (e), the 2001 Act contains no comparable provision. This omission may be inadvertent, or it may reflect an expectation that the states will follow the federal lead and repeal their death taxes, making such an adjustment superfluous.

116 Nevertheless, for each asset owned at death, the amount of appreciation and the fair market value must be known in order to determine the precise amount of the available basis increase and make an appropriate allocation. For the basis adjustments and mandatory allocation formulas under the 1976 Act, see former section 1023(c) (adjustment for federal and state estate taxes attributable to appreciation in property subject to tax), (d) (minimum basis adjustment for each asset in proportion to share of net appreciation), (e) (adjustment for certain state death taxes attributable to appreciation in property subject to tax), (h) (fresh start adjustment). 
only become more pressing as the scheduled effective date draws closer.

In general, the 2001 Act gives the executor broad discretion to allocate available basis increases to any appreciated property owned at death, subject to a fair market value limitation. The executor makes the allocation on an information return setting forth specified information about the property, the recipient, and the amount of the allocation. ${ }^{117}$ Information returns are required for "large transfers," i.e., property other than cash with an aggregate value of more than $\$ 1,300,000$ as well as certain gifts received by the decedent within three years before death. ${ }^{118}$ The reporting requirements are backed up by statutory penalties for noncompliance. ${ }^{119}$

\section{A. Proving Basis}

Any carryover basis regime raises the issue of ascertaining the basis of property in the decedent's hands. The issue does not arise under current law because property passing from a decedent generally takes a stepped-up (or stepped-down) basis in the recipient's hands equal to the value of the property for estate tax purposes. ${ }^{120}$ In contrast, under a carryover basis regime, the decedent's basis represents the starting point for determining the recipient's basis and ultimately the amount of gain or loss on a subsequent sale. Since property may pass through the hands of several generations of holders before it is sold, a carryover basis regime may impose substantial recordkeeping burdens over long periods of time. ${ }^{121}$

117 See I.R.C. $\$ \S 1022(\mathrm{~d})(3)(\mathrm{A}), 6018$.

${ }^{118}$ See I.R.C. $\$ 6018$.

119 The statute prescribes penalties of $\$ 10,000$ for failure to furnish information to the Service with respect to a large transfer, $\$ 500$ for failure to furnish information to the Service with respect to a transfer covered by the three-year rule, and $\$ 50$ for failure to furnish required information to a recipient. See I.R.C. $\$ 6716(a)$-(b). The statute provides an exception for "reasonable cause." See I.R.C. § 6716(c). If the failure is due to "intentional disregard," the penalty is $5 \%$ of the fair market value of the property involved. See I.R.C. \$ 6716(d).

${ }_{120}$ See I.R.C. $\$ 1014(a)$; Treas. Reg. $\$ 1.1014-1$ (a) (as amended in 1971).

121 Under the 1976 Act, if the facts necessary to determine the basis of property in the decedent's hands were unknown, basis was presumed to be equal to "the fair market value of such property as of the date (or approximate date) at which such property was acquired by the decedent or by the last preceding owner in whose hands it did not have a basis determined in whole or in part by reference to its basis in the hands of a prior holder." Former I.R.C. $\$ 1023(\mathrm{~g})(3)$. Current law makes a similar provision for property acquired by gift. See Treas. Reg. $\$ 1.1015-1$ (a)(3) (as amended in 1971). 
The practical problems of proving basis are likely to draw protests not only from individual taxpayers but also from politically influential interest groups involved with the administration of decedents' estates. Critics of the 1976 Act emphasized the difficulty of determining the basis of property held for many years with specific reference to closely-held businesses, farms, improved real estate, and tangible personal property. They insisted that individual taxpayers could not realistically be expected to maintain adequate basis records of each item of property owned at death. Furthermore, they argued that in the absence of such records the burden of reconstructing basis after death would lead to intolerable increases in the cost and delay of routine estate administration. ${ }^{122}$ These objections played an important part in bringing about the retroactive repeal of the 1976 carryover basis legislation, and they carry as much weight today as they did twenty-five years ago.

In response, defenders of carryover basis have pointed out that individual taxpayers are already responsible for maintaining basis records for purposes of lifetime dispositions; even under current law, they cannot know for certain whether they will hold specific property until death; and in any event, once the new carryover basis regime takes effect, it is perfectly reasonable to expect them to comply with recordkeeping requirements. ${ }^{123}$ Nevertheless, critics are likely to argue, as they did in 1976, that it is especially unfair to impose new recordkeeping burdens on taxpayers who acquired property many years ago with the expectation of holding it until death. ${ }^{124}$ As a practical matter, requirements that are widely perceived as unduly intrusive and burdensome may.prove to be unenforceable.

On the merits, defenders of carryover basis may argue that the difficulties of determining basis are simply overstated. Even if a

${ }^{122}$ See Carryover Basis Provisions: Hearing Before the House Comm. on Ways and Means, 96th Cong. 43, 45, 47-48 (1979) [hereinafter Carryover Basis Provisions] (statement of American Bankers Association); id. at 111, 113-14 (statement of American College of Probate Counsel); id. at 162, 168-69, 173 (statement of American Bar Association). See generally Zelenak, supra note 9, at 388-94.

${ }^{123}$ See Carryover Basis Provisions, supra note 122, at 9, 12-14 (statement of Donald C. Lubick, Assistant Secretary of the Treasury for Tax Policy); id. at 178, 18085 (statement of Paul R. McDaniel). Or, to put the point more bluntly, failure to keep required records does not mean that the requirement is unreasonable.

${ }^{124}$ The 2001 Act provides no transitional relief similar to the 1976 Act's "fresh start" basis adjustment for property acquired before the date of enactment. If carryover basis is viewed as a replacement for the estate tax, this omission makes sense. A fresh start adjustment, coupled with estate tax repeal, would represent an enormous windfall for holders of property with pre-effective date appreciation. 
decedent failed to keep detailed records, it may be possible to reconstruct the decedent's basis from other sources: land records and mortgage lenders in the case of real property; tax returns and corporate books in the case of closely-held business interests; brokers and other intermediaries in the case of financial assets; and insurance records in the case of jewelry and collectibles. ${ }^{125}$ Nevertheless, such records may be incomplete, unavailable, or fail to reflect adjustments to the decedent's original cost basis. For example, additional information may be necessary to make accurate basis determinations with respect to improved real property, or shares of stocks or mutual funds acquired in small increments over time pursuant to a reinvestment plan.

For some types of property, the burden of determining basis may be alleviated by a special exemption. For example, the 2001 Act expands the $\$ 250,000$ gain exclusion for principal residences to apply to qualifying property acquired from a decedent. ${ }^{126}$ A separate, limited exemption might plausibly be allowed in the case of tangible personal property held for personal use (as opposed to business or investment purposes), to avoid the cost and inconvenience of identifying and reporting numerous items with trivial amounts of appreciation. $^{127}$ The 2001 Act, however, provides no such exemption, perhaps on the ground that such property is unlikely to appreciate in value, and any decline would be nondeductible. As a result, executors may find themselves spending inordinate time and effort sifting through personal and household effects in search of items with potential appreciation (e.g., jewelry, wedding presents, collectibles, and the contents of the proverbial trunk in the attic). More likely, though, such property may simply slip through the system uncounted and unreported.

It is true, of course, that repeal of the estate tax will reduce the costs of administration and compliance directly attributable to preparing and filing estate tax returns, as well as some related costs of planning and drafting. The administration of decedents' estates will

125 See Carryover Basis Provisions, supra note 122, at 9, 12-14 (statement of Donald C. Lubick, Assistant Secretary of the Treasury for Tax Policy); id. at 178, 18183 (statement of Paul R. McDaniel).

${ }^{126}$ See I.R.C. $\$ 121(\mathrm{~d})(9)$ (effective for property acquired from decedents dying after 2009).

${ }^{127} C$ f. former I.R.C. $\S 1023$ (b)(3) (\$10,000 exclusion for personal and household effects). The purpose of such an exemption would be "to eliminate the burdensome task of determining whether or not innumerable and often trivial personal effects have appreciated value." Graetz, supra note 51 , at $843-44$; see also Zelenak, supra note 9 , at $425-28$. 
still involve substantial costs, ${ }^{128}$ however, and the efforts required of taxpayers, executors, and beneficiaries to collect and maintain basis records under the new carryover basis regime may well prove even more onerous. ${ }^{129}$ Some of the groups that complained so loudly of the burdens of proving basis under the 1976 Act have already begun to express similar reservations about the new carryover basis regime, and there is no reason to expect that their concerns will diminish with the passage of time. ${ }^{130}$

\section{B. Information Reporting}

The 2001 Act imposes new information reporting requirements which, if diligently followed, may prove even more burdensome for executors than filing estate tax returns. On the information return, which is due on the same date as the decedent's final return, the executor must provide detailed information with respect to any property acquired from the decedent, including the name of the recipient, the fair market value of the property at death, the decedent's adjusted basis and holding period, and the amount of any basis increase allocated to the property. ${ }^{131}$ This information is considerably more extensive than the disclosure required on an estate

${ }^{128}$ See, e.g., Charles Davenport \& Jay A. Soled, Enlivening the Death-Tax DeathTalk, 84 TAX NOTES 591, 621 (July 26, 1999) ("Even without an estate tax, assets must be marshalled, debts must be paid, heirs must be pacified, property must be valued, special orders may be sought, asset schedules must be prepared, claims and debts must be listed, income and expenses must be tracked, and many costs are incurred unrelated to the estate tax.").

${ }^{129}$ See Roby B. Sawyers, Restructuring Estate and Gift Taxes, 54 NAT'L TAX J. 579, 587 (2001) (noting likelihood of increased administration costs due to retention of accountants, lawyers and other professionals "to review a lifetime's accumulation of bills, checks, insurance policies, and other records to determine the acquisition dates and prices of a multitude of assets" and calculate bases).

${ }^{130}$ See AICPA Tax Division, Reform of the Estate and Gift Tax System, 91 TAX NoTES 307, 323 (Apr. 9, 2001) (noting "significant problems" of determining basis for collectibles, other personal property and household goods, mutual funds and listed securities); President's Tax Relief Proposals: Individual Income Tax Rates: Hearing Before the House Comm. on Ways and Means, 107th Cong. 103 (2001) (statement of American Bankers Association) (describing carryover basis as an "administrative nightmare" and noting increased administration costs and burden of determining basis); Tucker, supra note 113, at 165-66.

${ }^{131}$ See I.R.C. $\$ 6018(\mathrm{c})$. In addition, the executor must report the recipient's taxpayer identification number, information concerning the character of any gain on sale of the property, and any other information prescribed by regulations. See id. The executor must also furnish a separate statement containing similar information to the recipient of the property. See I.R.C. $\$ 6018(\mathrm{e})$. 
tax return under current law. For example, while disclosure of the decedent's basis and holding period is essential to the operation of the new carryover basis regime, this represents a completely new task for the executor. Even assuming that the executor is able to gather or reconstruct all of the required information, ${ }^{132}$ doing so will require substantial time and effort and will inevitably increase the cost of administering decedents' estates. Compliance will be especially difficult in the case of a pecuniary bequest since the executor may not identify the particular assets which will fund the bequest until long after the deadline for filing the information return.

At first glance, the information reporting requirements may seem to apply only to a relatively small group of estates worth more than $\$ 1,300,000 ;{ }^{133}$ however, the requirements are much more far-reaching. Initially, the executor must identify all property (other than cash) acquired from the decedent to see whether the aggregate fair market value exceeds the statutory threshold. ${ }^{134}$ Unfortunately, aside from the core category of probate assets passing by bequest, devise, or inheritance, the statutory definition of "[p]roperty acquired from the decedent" is quite vague. ${ }^{135}$ Although the term evidently does not embrace all property included in the gross estate under current law, its application to certain transfers made during life ${ }^{136}$ or outside the

132 If some of the required information is unavailable, the executor must nevertheless describe the property and identify each person holding a legal or beneficial interest therein. See I.R.C. $\$ 6018(b)(4)$.

133 For information reporting purposes, the statutory threshold is equal to $\$ 1,300,000$, "the dollar amount applicable under section 1022(b)(2)(B) (without regard to [the adjustment for certain loss carryovers and built-in losses under] section 1022(b)(2)(C))." I.R.C. $\$ 6018(b)(1)$. It is unclear whether the threshold amount is subject to the inflation adjustment under section 1022(d)(4).

${ }^{134}$ The statute expressly excludes cash. See I.R.C. $\$ 6018(b)(1)$. This may reflect the notion that the carryover basis provisions cannot apply to cash. Nevertheless, if the threshold is intended to identify "[l]arge transfers," as the statutory heading implies, it seems odd to exclude cash. Apparently an estate consisting of $\$ 1$ billion of cash and $\$ 1,000,000$ of appreciated securities would not constitute a "[l]arge transfer" for information reporting purposes.

${ }^{135}$ In addition to property passing by bequest, devise or inheritance, the definition includes property transferred by the decedent during life to a "qualified revocable trust" (or any other trust subject to a reserved power to "alter, amend, or terminate") and property "passing from the decedent by reason of death" without consideration. I.R.C. $\$ 1022(\mathrm{e})$. The same definition applies for purposes of the information reporting requirements. See I.R.C. $\$$ 6018(d).

136 For example, it is unclear whether the definition includes a trust that can be revoked by the decedent only with the consent of an adverse party; a trust that can be altered, amended or terminated by the decedent only with the consent of another 
probate system at death ${ }^{137}$ remains unclear. The definition of property "owned" by the decedent at death, which determines which property is eligible for a basis increase at death, is even sketchier. ${ }^{138}$ The result is a pastiche of concepts borrowed from the provisions of current law allowing a deathtime basis step-up, ${ }^{139}$ which lacks coherence in the absence of the estate tax. ${ }^{140}$

Regardless of whether the $\$ 1,300,000$ threshold is met, the executor must report certain gifts of property received by the decedent within three years before death. ${ }^{141}$ Specifically, the reporting requirement applies to "appreciated property acquired from the decedent" that is ineligible for a basis increase due to the three-year rule $^{142}$ and that was required to be included on a gift tax return. ${ }^{143}$ This provision is apparently intended to encourage disclosure of gifts triggering the three-year rule by invoking penalties for failure to report such gifts on the information return.

Although the reporting requirements nominally apply only to

person; or a revocable transfer not in trust (e.g., a conveyance of land subject to a retained life estate and power of revocation).

${ }^{137}$ Presumably, "property passing from the decedent by reason of death" includes a nonprobate transfer such as a pay-on-death beneficiary designation. See I.R.C. $\$ 1022(\mathrm{e})(3)$. Less obviously, this catch-all term may also include property held in joint tenancy (or tenancy by the entirety), at least to the extent such property is treated as "owned by the decedent" at death and hence eligible for a basis step-up under section 1022(b) or (c). See H.R. REP. No. 107-37, at 26-27 (2001); cf. I.R.C. $\S 1022(\mathrm{~d})(1)(\mathrm{B})(\mathrm{i})$ (treating one-half of property as owned at death in case of marital joint tenancy, or, in case of other joint tenancy, a proportional share attributable to consideration furnished by decedent). Apparently, any nonprobate transfer that falls outside the statutory definition is treated as a transfer by gift subject to section 1015 , with the result that the property is not eligible for a basis increase under section 1022 .

138 The statutory definition specifically includes a portion of property held in joint tenancy (or tenancy by the entirety), a "qualified revocable trust," and a surviving spouse's one-half share of community property; it does not include property subject to a power of appointment. See I.R.C. \& 1022(d)(1)(A)-(B).

139 See I.R.C. $\$ 1014(\mathrm{~b})(1),(3),(6)$.

${ }^{140}$ For purposes of the deathtime basis step-up under current law, the definition of "property acquired from the decedent" generally includes property includible in the decedent's gross estate. See I.R.C. $\S 1014(b)(9)$. With the repeal of the estate tax, this provision loses its significance. An earlier carryover basis bill, approved by Congress but vetoed by President Clinton in 2000, defined "property acquired from a decedent" by reference to the concept of the gross estate under current law. See Death Tax Elimination Act of 2000, H.R. 8, 106th Cong. $\S 103$ (proposed $\S$ 1022(b)(1)).

${ }^{141}$ See I.R.C. $\$ 6018(b)(2)$.

${ }^{142}$ See supra notes $99-105$ and accompanying text.

${ }^{143}$ See I.R.C. $\$ 6018(\mathrm{~b})(2)(\mathrm{B})$. 
estates above the $\$ 1,300,000$ threshold and gifts subject to the threeyear rule, the practical impact of the requirements is much broader. In fact, an executor must file an information return in order to make a valid allocation of any allowable basis increase regardless of the amount of property involved. ${ }^{144}$ Thus, the technical reporting requirements for allocating a basis increase are the same for a $\$ 10,000$ estate as for a $\$ 20,000,000$ estate. $^{145}$ This represents a substantial (and probably unintended) new administrative burden for estates that receive a full basis step-up under current law without having to file an estate tax return. Moreover, if no executor (or administrator) is appointed, the recipients themselves may be required to file information returns. ${ }^{146}$ Especially in cases where the basis or value of particular property is uncertain, there is a serious possibility of inconsistent reporting by several recipients with conflicting interests.

Even assuming full compliance on the part of executors, the 2001 Act fails to establish a procedure for auditing information returns or finally determining an adjusted basis that would be binding on a recipient in a subsequent sale of property acquired from a decedent. With the repeal of the estate tax, no tax will be imposed by reason of an individual taxpayer's death, and there will be no pressing reason for the Service to review the accuracy or completeness of information returns submitted by executors. Indeed, there appears to be no procedure for finally and conclusively establishing the basis of property acquired from a decedent prior to the eventual disposition of the property. ${ }^{147}$ The recipient of such property, though entitled to receive a separate information return from the executor, has no opportunity to challenge the accuracy or completeness of the adjusted basis shown on the return. Indeed, nothing in the 2001 Act gives

144 See I.R.C. $\$ 1022(\mathrm{~d})(3)(\mathrm{A})$ (providing for allocation of basis increase by executor on information return).

145 The executor is also required to furnish similar information to the recipients, who as a practical matter must in turn keep records to prove basis in the event of a subsequent disposition. See I.R.C. $\$ 6018(\mathrm{e})$.

146 The statute defines "executor" to include a decedent's executor or administrator or, if none is appointed, qualified and acting in the United States, "any person in actual or constructive possession of any property of the decedent." I.R.C. $\S 7701(\mathrm{a})(47)$. See also I.R.C. $\$ 6018(\mathrm{~b})(4)$ (requiring information return in certain cases by person with legal or beneficial interest).

${ }^{147}$ See Dodge, supra note 69, at 969 (noting that "any determination of basis reported on an information return would not become final until the statute of limitations runs on the reported gain or loss generated by such basis"). The regular deficiency procedures do not apply to assessment or collection of penalties under section 6716. See I.R.C. $\$ 6716(\mathrm{e})$. 
binding effect to the information furnished by the executor in determining the recipient's adjusted basis. Apparently, the recipient is free to make an independent (and possibly inconsistent) calculation of adjusted basis in property acquired from the decedent for purposes of determining gain or loss on a subsequent disposition. Without an effective mechanism for conclusively determining the basis of property acquired from the decedent (as adjusted for any allowable increase at death) and giving binding effect to that determination of basis on a subsequent disposition, the entire carryover basis regime collapses like a house of cards.

\section{Allocation of Basis Increase}

Another problem lurking beneath the surface of the new carryover basis regime involves the method of allocating basis increases to property owned at death. The 2001 Act gives the executor broad discretion to allocate any available basis increase to appreciated property owned at death, subject to the limitation that the resulting adjusted basis may not exceed the property's fair market value at death. ${ }^{148}$ This represents a sharp departure from the mandatory allocation formula approach of the 1976 Act, which implicitly made the basis adjustment for each asset depend on a precise calculation of the basis and fair market value of each appreciated asset in the decedent's estate. ${ }^{149}$ Although the 2001 Act avoids some of the problems of a mandatory allocation formula, it raises several new pitfalls and opportunities for executors and beneficiaries.

The discretionary allocation approach invites executors to make tax-motivated allocations that maximize gain deferral and minimize the potential income tax liability of beneficiaries as a group. Executors will have a powerful incentive to allocate any available basis increase selectively to property with built-in ordinary gain, property passing to recipients in high income tax brackets, or property expected to be sold shortly after death. ${ }^{150}$ The new regime does not restrict the use of such techniques, nor does it provide a default

${ }^{148}$ See I.R.C. $\$ \S 1022(d)(3)(A)$ (authorizing executor to allocate basis increase on information return), 1022(d)(2) (specifying fair market value limitation).

149 See former I.R.C. $\S 1023$ (d) (providing minimum basis adjustment for each asset in proportion to its share of net appreciation).

150 See Dodge, supra note 69, at 964 (noting problem of selective allocation of basis increase). However, such allocations cannot be made to items of IRD, which are ineligible for any basis increase. See I.R.C. $\S 1022(\mathrm{f})$. 
allocation rule in cases where the executor fails to act affirmatively. Indeed, in the case of a small estate where no executor is appointed and no information return is filed, the basis increase may be lost entirely. The legislative history gives no indication that the drafters gave any consideration to the implications of unlimited discretion.

Furthermore, the allocation provisions fail to address the problem of "suspended basis" arising when the executor sells appreciated property (or distributes the property in kind to satisfy a pecuniary bequest ${ }^{151}$ ) after death and before making a final allocation of basis increase. ${ }^{152}$ Assuming that the sale cannot be delayed, the executor is in the awkward position of making important administrative decisions - which property to sell, whether to make a provisional allocation of basis increase - without full information about the nature and extent of the decedent's property or the optimal overall allocation of available basis increases. ${ }^{153}$ As further information becomes available, the executor may have to review and revise provisional allocation decisions. A beneficiary who receives a simple distribution of appreciated property in kind cannot know the adjusted basis of the property until the executor files an information return reflecting a final allocation of basis increase. ${ }^{154}$ Given the likely delay in determining the fair market value and basis of all the decedent's property and making a final allocation of basis increases, the estate and the beneficiaries may find themselves routinely forced to seek extensions for filing their respective income tax returns.

Finally, the allocation provisions pose new dilemmas for

151 In the case of an in-kind distribution of appreciated property to satisfy a pecuniary bequest, the 2001 Act limits the estate's recognized gain to post-death appreciation (i.e., the increase in fair market value from the date of death to the date of distribution). See I.R.C. $\$ 1040$ (a) (effective for estates of decedents dying after 2009). This provision, however, does not solve the problem of suspended basis. The recipient takes a carryover basis in the property, including any deathtime basis increase allocated by the executor, increased by any gain recognized on the distribution. See I.R.C. $\$ 1040$ (c). Thus, the basis of the property in the recipient's hands still depends on knowing the amount of any basis increase finally allocated to the property.

${ }^{152}$ This problem arose in even more acute form under the 1976 Act, which required an allocation of basis increase among all appreciated assets in proportion to the net appreciation in each asset. See supra note 149 and accompanying text.

${ }^{153}$ Even the total amount of the available basis increase may be uncertain until the decedent's built-in section 165 losses are ascertained. See I.R.C. $\S 1022$ (b)(2)(C)(ii).

${ }^{154}$ This may prove inconvenient if the recipient sells the property or claims depreciation deductions by reference to the property's (as yet unascertainable) adjusted basis. 
executors in discharging their fiduciary duties under state law. In administering a decedent's estate, an executor owes fundamental duties to the decedent's beneficiaries, including the duties of loyalty, ${ }^{155}$ care, ${ }^{156}$ and impartiality. ${ }^{157}$ Even under current law, an executor may find it difficult to reconcile these duties, especially in making tax elections. ${ }^{158}$ In giving the executor virtually unlimited discretion to allocate basis increases, the 2001 Act makes matters worse. To minimize the overall tax burden on the beneficiaries, the executor may be inclined to allocate basis increase to property passing to a beneficiary in a high income tax bracket. If this allocation has the incidental effect of leaving another beneficiary with a lower basis (and more built-in gain), the executor may be charged with favoring the former beneficiary at the expense of the latter in violation of the duty of impartiality. ${ }^{159}$ A variation of the same problem arises if the executor makes in-kind distributions of properties with the same fair market value but different amounts of built-in gain to satisfy equivalent pecuniary bequests. The recipient of the low-basis property may insist that the duty of impartiality requires that the executor allocate any available basis increase in a manner that equalizes built-in gain or at least reduces disparities between the two beneficiaries. The recipient of the high-basis property, of course, is likely to take a different view. In an estate comprising many different assets and beneficiaries with diverse tax characteristics, it may be

155 In general, the duty of loyalty requires that the executor act solely for the benefit of the beneficiaries and avoid transactions tainted by self-dealing or conflict of interest. See RestatemEnT (SECOND) OF TRusts $\$ 170$ (1959).

156 The duty of care requires that the executor exercise due care and skill, including filing tax returns and making tax elections. See RESTATEMENT (SECOND) OF TRUSTs $\$ 174$ (1959). The executor may delegate some of these functions to agents, but remains responsible for exercising due care in selecting and monitoring agents. Restatement (ThIRD) OF TRusts: Prudent INVESTOR Rule $\$ 171$ (1992).

157 The duty of impartiality requires that the executor treat beneficiaries fairly and avoid favoring one beneficiary or class of beneficiaries at the expense of others. See RESTATEMENT (SECOND) OF TRUSTs § 183 (1959).

${ }^{158}$ For example, under current law the executor may be able to reduce the overall tax burden by electing to deduct administration expenses on the estate's income tax return rather than on the estate tax return. For fiduciary accounting purposes, such expenses may be charged against principal, even though the income tax deduction increases net income. To avoid a windfall for the income beneficiaries, the executor may be authorized to make an equitable adjustment in favor of the remainder beneficiaries. See UNIF. PRINCIPAL AND InCOME ACT § 506, 7B U.L.A. 131 (1997) (authorizing equitable adjustments).

159 The duty of loyalty may also be implicated if the high-bracket beneficiary happens to be the same person as (or someone closely affiliated with) the executor. 
impossible to reconcile the competing interests of all beneficiaries satisfactorily. ${ }^{160}$ Although estate administration often involves unavoidable tensions among beneficiaries with divergent interests, the advent of discretionary allocations under the new regime will aggravate those tensions and expose executors to an increased risk of liability.

Executors will most likely respond by pressing for exoneration provisions in wills to shield them from complaints by disappointed beneficiaries. Even broad exoneration provisions, however, will not prevent beneficiaries from second-guessing the executor's discretionary allocations of basis increase. The executor in turn may be obliged to investigate various alternative allocations in search of an optimal tax result, thereby driving up the costs of routine estate administration. Those costs will rise even more sharply if a disgruntled beneficiary resorts to litigation. Increased costs will exacerbate the executor's dilemma since cost containment represents an important component of the basic duty of care. In sum, the executor's broad discretion to allocate basis increases under the 2001 Act may well prove even more cumbersome, time-consuming, and wasteful in terms of estate administration costs than either the mandatory allocation formulas of the 1976 Act or the estate tax reporting requirements of current law.

\section{A Stand-Alone Gift TAX}

Although the 2001 Act repeals the estate tax (and the generationskipping transfer tax) in conjunction with the introduction of the new carryover basis regime, it leaves the gift tax in place. This development is both unprecedented and puzzling, for the gift tax has traditionally been viewed as an important but subordinate buttress to the estate tax. Whatever the underlying rationale, a stand-alone gift tax fits uneasily with the new regime and raises serious questions concerning the long-term viability of the 2001 legislative package.

For many years, the gift tax has functioned as a backstop to the estate tax, ensuring that the estate tax base cannot be too easily eroded by large lifetime transfers. ${ }^{161}$ The estate and gift taxes are

160 See Dodge, supra note 69, at 972 ("Lots of legatees are going to be unhappy.").

${ }^{161}$ See Sanford's Estate v. Commissioner, 308 U.S. 39, 44 (1939). In addition, the gift tax serves as a backstop to the progressive rate structure of the income tax. See H.R. REP. No. 72-708, at 28 (1932), reprinted in 1939-1 C.B. (Part 2) 457, 462; S. REP. No. $72-665$ (1932), reprinted in 1939-1 C.B. (Part 2) 496, 504; see also Dickman v. 
"closely related both in structure and in purpose." taxes have shared a common set of "unified" rates and exemptions. ${ }^{163}$ Nevertheless, the correlation between the two taxes remains imperfect. For example, notwithstanding the unified rate schedule, the gift tax is effectively imposed at lower rates than the estate tax, due to the difference between the "tax-exclusive" base of the former and the "tax-inclusive" base of the latter. ${ }^{164}$ This systematic preference for lifetime gifts, though conceptually untidy, has occasionally been defended as a useful subsidy that encourages the flow of business and investment capital from older generations into the hands of "younger, more vigorous owners." 165 In response, it has been observed that dynastic wealth is often held in long-term trusts and that a shift from older to younger beneficiaries is unlikely to have any impact on the low-risk, low-return investment strategies traditionally pursued by trustees. ${ }^{166}$ The empirical evidence, though sparse, suggests a surprisingly low level of taxpayer responsiveness to the tax incentives for making lifetime gifts. ${ }^{167}$

Evidently, a stand-alone gift tax turns the argument for subsidizing lifetime gifts on its head. In the absence of the estate tax, the gift tax will discourage taxpayers from making substantial lifetime gifts and reinforce their deep-rooted instinct to hold on to their accumulated wealth until death. ${ }^{168}$ The incentive to retain wealth will

Commissioner, 465 U.S. 330, 338-39 (1984).

162 Burnet v. Guggenheim, 288 U.S. 280, 286 (1933); see also Sanford's Estate, 308 U.S. at 44; Merrill v. Fahs, 324 U.S. 308, 311-13 (1945).

163 See I.R.C. $\$ \S 2001$ (c) (estate tax rates), 2010 (estate tax unified credit), 2502 (gift tax rates), 2505 (gift tax unified credit). The 2001 Act freezes the gift tax exemption at $\$ 1,000,000$, while raising the estate tax exemption to $\$ 3,500,000$ by 2009 . See I.R.C. $\$ \S 2010($ c), 2505(a)(1).

${ }^{164}$ See Harry L. Gutman, A Comment on the ABA Tax Section Task Force Report on Transfer Tax Restructuring, 41 TAX LAw. 653, 656-57 (1988).

165 See Am. Bar Ass'n, Section of Taxation, Task Force on Transfer Tax Restructuring, Report on Transfer Tax Restructuring, 41 TAX LAW. 395, 403 (1988); Paul B. Stephan III, A Comment on Transfer Tax Reform, 72 VA. L. REV. 1471, 148788 (1986) (suggesting that tax preference for lifetime gifts may "nudge wealth out of the hands of aging owners and into the possession of younger, more productive entrepreneurs").

166 See Gutman, supra note 164 , at 656-57.

${ }^{167}$ See James Poterba, Estate and Gift Taxes and Incentives for Inter Vivos Giving in the US, 79 J. PUB. ECON. 237, 252-59 (2001).

${ }_{168}$ Presumably, the relinquishment or termination of ownership or retained powers at death will not constitute a deemed transfer for gift tax purposes. See Treas. Reg. \$ 25.2511-2(f) (as amended in 1999) (treating relinquishment or termination of retained power "occurring otherwise than by the death of the donor" as deemed 
be strengthened by the prospect of a limited basis step-up at death; the large exemptions from the new carryover basis regime have no counterpart in the income tax treatment of lifetime gifts. ${ }^{169}$ Accordingly, the distinction between lifetime and deathtime transfers will assume new importance. Deathtime transfers will enjoy an unequivocal tax advantage over lifetime gifts since they will escape transfer tax altogether and at the same time be eligible for a basis increase. Thus, the 2001 Act will likely have the perverse effects of deterring lifetime gifts and exacerbating lock-in.

The obvious question is why the 2001 Act preserves the gift tax at all. One possible answer is that the gift tax is necessary to protect the integrity of the progressive income tax rate structure by discouraging bracket-shifting techniques. ${ }^{170}$ For example, in the absence of a gift tax, a high-bracket taxpayer might give appreciated property to a lower-bracket friend or family member with the expectation that the donee would sell the property, pay income tax (at a relatively low rate) on the resulting gain and eventually return the after-tax proceeds to the donor. ${ }^{171}$ Interestingly, the original bill passed by the House called for repeal of the gift tax, but it also contained an antiabuse provision authorizing the Service to disregard a gift of property for income tax purposes in order to prevent income tax avoidance. ${ }^{172}$ The gift tax was reinstated by a Senate amendment, and it survived in the final version of the bill approved by the conference committee. ${ }^{173}$

Two substantive changes included in the 2001 Act seem to

transfer, and noting that the gift tax is "confined to transfers by living owners").

${ }^{169}$ Compare I.R.C. $\$ 1022$ (b), (c) (allowing basis increase for property owned at death), with I.R.C. $\S 1015$ (a), (d) (providing carryover basis for lifetime gifts, with limited basis adjustment for gift tax attributable to net appreciation).

${ }^{170}$ See John Buckley, Estate and Gift Taxes: What Will Congress Do Next?, 91 TAx Notes 2069, 2070 (June 18, 2001) ("Retention of the gift tax is an attempt to prevent widespread income tax avoidance.").

171 Similarly, the donor might seek to reduce income tax liability by transferring income-producing property abroad or by using an "adverse party" to avoid grantor status for a transfer in trust. See Blattmachr \& Gans, supra note 53, at 574-75; John Buckley, Transfer Tax Repeal Proposals: Implications for the Income Tax, 90 TAX Notes 539 (Jan. 22, 2001).

${ }^{172}$ See Death Tax Elimination Act of 2000, H.R. 8, 106th Cong. § 402(e) (proposed I.R.C. $\$ 7701(\mathbf{n})$ ). The House bill also called for "a study of opportunities for avoidance of the income tax, if any, and potential increases [sic] in income tax revenues by reason of enactment of the bill." H.R. REP. No. 107-37, at 31 (2001); cf. id. at 195-96 (views of dissenting committee members, noting problem of income tax avoidance under original House bill).

173 See H.R. REP. No. 107-84, at 189, 191 (2001). The anti-abuse rule proposed in the original House bill was also dropped in the conference agreement. 
confirm the notion of the gift tax as a deterrent to income shifting. First, in 2010, simultaneously with the repeal of the estate tax, the top marginal gift tax rate is scheduled to drop to $35 \%,{ }^{174}$ precisely matching the top marginal individual income tax rate. ${ }^{175}$ Second, the Act rewrites the gift tax rules for determining when and to what extent a transfer of property in trust is complete. In place of the current rules, which reflect a patchwork of early Supreme Court rulings, ${ }^{176}$ the Act announces a single overriding rule: a "transfer in trust shall be treated as a transfer of property by gift, unless the trust is treated as wholly owned by the donor or the donor's spouse under [the grantor trust rules of sections 671-679]." ${ }^{177}$ By conforming the gift tax completion rule to the existing income tax grantor trust rules, the Act in effect imposes the gift tax as a toll charge on any transfer that shifts income tax liability in whole or in part from the donor (or the donor's spouse) to another taxpayer. ${ }^{178}$

Aside from technical issues, the decision to retain the gift tax while repealing the estate tax raises a fundamental question of policy. Simply put, there is little reason to believe that a stand-alone gift tax represents an appropriate response to concerns about income shifting. In part, this is because the scope of the income-shifting problem has dwindled in recent years as individual income tax rates have become increasingly compressed. In part, it is because the sheer complexity and administrative burden of a stand-alone gift tax (combined with serious enforcement problems under current law) seem grossly disproportionate to the goal of deterring high-bracket parents from using gifts of property to shift income into the hands of low-bracket children. ${ }^{179}$ And in part, it is because the structure of the gift tax, with its generous exclusions and exemptions, reaches only a very small

${ }^{174}$ See I.R.C. $\$ 2502(\mathrm{a})(2)$ (gift tax rates for gifts made after 2009). In effect, the first $\$ 1,000,000$ of cumulative gifts are exempt from gift tax, and subsequent gifts are taxed at a flat marginal rate of 35\%. See I.R.C. $\$ \S 2502(a)(2)$ (specifying 35\% rate for cumulative gifts over $\$ 500,000), 2505$ (a)(1) (allowing $\$ 1,000,000$ exemption).

175 See I.R.C. $\$ 1(\mathrm{i})(2)$.

176 See Treas. Reg. $\S \S 25.2511-1$ (as amended in 1997), 25.2511-2 (as amended in 1999).

${ }^{177}$ See I.R.C. $\$ 2511$ (c) (effective for gifts made after 2009).

178 The new rule appears to be aimed at a narrow category of transfers in trust that are wholly or partially complete for income tax purposes but not for gift tax purposes.

179 Indeed, in view of the relatively compressed rate brackets, it might also be questioned whether provisions such as the grantor trust rules and the "kiddie tax" are worth retaining. 
fraction of lifetime gifts. ${ }^{180}$ On the whole, a stand-alone gift tax seems remarkably cumbersome and ineffective as a means of combating income shifting.

A stand-alone gift tax also creates a substantial disincentive for lifetime gifts. A much more direct and effective method of reaching wealth transfers would be to repeal the income tax exclusion for gifts and bequests ${ }^{181}$ and to include such transfers in the recipient's gross income. ${ }^{182}$ Admittedly, this approach runs counter to the basic premise of a carryover basis regime, for it implies that the recipient would take the transferred property with a fair-market-value basis (reflecting the amount included in gross income) and that the transferor would realize any built-in gain at the time of the transfer. ${ }^{183}$ Furthermore, regardless of its merits as a conceptual matter, the notion of a double-level income tax on gifts and bequests is clearly a nonstarter as a practical matter in the current political climate.

Perhaps the most convincing explanation for the persistence of the gift tax under the new regime is rooted not in policy but in politics. It seems possible, indeed likely, that a stand-alone gift tax is not really intended to mitigate the revenue loss resulting from estate tax repeal or to deter income shifting through lifetime gifts. ${ }^{184}$ Instead, the gift tax may represent merely a tactical measure to disguise the impact of the new regime and to disarm critics without seriously affecting revenue or behavior. Under the new carryover basis regime, few taxpayers will pay any gift tax at all. Most routine lifetime gifts will be

${ }^{180}$ See I.R.C. $\$ \$ 2503$ (b) (excluding over $\$ 10,000$ of annual gifts to each donee), 2505 (a) (allowing credit to offset gift tax on first $\$ 1,000,000$ of cumulative taxable gifts).

${ }^{181}$ See I.R.C. $\S 102$.

${ }^{182}$ See John K. McNulty, Fundamental Alternatives to Present Transfer Tax Systems, in DeAth, TAXes AND Family Property 85, 95 (Edward C. Halbach, Jr. ed., 1977) (describing an income tax on gifts and bequests as an "elegantly simple and economically attractive alternative" to the estate and gift taxes); see also HENRY C. Simons, Personal Income Taxation 125-47 (1938); Joseph M. Dodge, Beyond Estate and Gift Tax Reform: Including Gifts and Bequests in Income, 91 HARV. L. REV. 1177, 1182-95 (1978).

${ }^{183}$ See Burke \& McCouch, supra note 10, at 546-53 (pointing out that "treating gifts and bequests as income to the recipient appears to be feasible primarily, and perhaps exclusively, in the context of a full double level tax model").

${ }^{184}$ Cf. Paull's March Memo to W\&M Counsel on Estate and Gift Tax Estimates, TAX Notes TodAy (Mar. 26, 2001) (LEXIS, FEDTAX lib., TNT file, elec. cit,, 2001 TNT 60-43) (noting "significant revenue effects that result from a variety of income tax avoidance opportunities made possible by the repeal of the estate and gift tax" and suggesting that revenue loss could be reduced by adding "provisions to prevent income tax avoidance and to enhance compliance"). 
nontaxable, due to the exclusions for annual gifts of over $\$ 10,000$ for each recipient and unlimited amounts for medical and educational expenses, and all but a handful of larger gifts will be fully covered by the $\$ 1,000,000$ lifetime exemption. ${ }^{185}$ Taxpayers will have irresistible tax incentives to hold appreciated property until death to avoid the gift tax and obtain substantial basis increases. Even under current law, gift tax compliance is notoriously uneven, depending to a large extent on voluntary disclosure to take advantage of limitations on assessment ${ }^{186}$ or on mandatory disclosure in connection with the estate tax return. ${ }^{187}$ With the repeal of the estate tax, there is no reason to suppose that the gift tax would flourish; the more likely prediction is that it would atrophy through disuse and would eventually be repealed as a dead letter. ${ }^{188}$ From this perspective, leaving a standalone gift tax on the books may represent no more than an empty gesture.

\section{CONCLUSION}

In the abstract, a carryover basis regime for inherited property represents a plausible alternative to the unlimited basis step-up allowed under current law. Properly designed and implemented, a carryover basis regime could reduce existing disparities in the income tax treatment of transfers made during life and at death. ${ }^{189}$ But, as demonstrated by the experiment with carryover basis under the 1976 Act, in the real world an ideal version of carryover basis is unlikely to be enacted, and a defective version is unlikely to survive for long. The carryover basis regime under the 2001 Act is far from ideal. Gutted by huge exemptions, marred by vagueness and complexity, and hobbled by unacknowledged problems of implementation, the new carryover basis regime may be damaged beyond repair even before it takes effect. Given the trivial amount of revenue that it would raise, the disproportionate costs of administration, and the lack of workable enforcement mechanisms, it is difficult to imagine that the new

185 See I.R.C. $\$ \S 2503$ (b) (annual exclusion), 2503(e) (medical and educational exclusion), 2505(a) (gift tax unified credit).

${ }^{186}$ See I.R.C. $\$ \S 2504$ (c) (limitation on revaluation of gifts), 6501(c)(9) (exception to open limitation period for adequate disclosure on gift tax return).

187 Indeed, many gift tax cases come to light only after the donor's death in connection with an audit of the estate tax return.

${ }^{188}$ See Buckley, supra note 170, at 2070 (expressing "doubt as to whether retention of the gift tax in an environment with no estate tax is a politically viable answer to the income tax avoidance issue").

189 See Joulfaian, supra note 90 , at 642. 
carryover basis regime will actually come into force in 2010 .

This should come as no surprise. The 2001 Act reflects a relentless determination on the part of its abolitionist sponsors to repeal the estate tax. Next to this primary goal, the carryover basis provisions play only a minor supporting role. Although the abolitionists thus far have achieved only temporary repeal, they have already launched a fresh campaign to override the sunset provision and make estate tax repeal permanent. If they succeed, it is entirely foreseeable, and perhaps inevitable, that the new carryover basis regime and the stand-alone gift tax will disappear as well.

Opponents of the abolitionist agenda propose to retain the estate tax with substantially higher exemptions and lower rates. Their defense of the estate tax is lukewarm, for they recognize well the shortcomings of the current system. Instead, they view the estate tax as less objectionable than alternative options such as carryover basis or a deathtime gains tax that would raise far less revenue and contribute much less to the progressivity of the overall tax system. Their proposals, however, have encountered vigorous opposition from the abolitionists, who correctly perceive that any immediate increase in the estate tax exemption would siphon off political support for complete repeal.

The abolitionist strategy behind the 2001 Act represents an enormous fiscal and political gamble. The Act sets in motion a series of tax cuts that have already exhausted the short-term non-socialsecurity surplus and promise, if they become permanent, to produce even larger revenue losses in the future. ${ }^{190}$ It is not clear whether the predominant long-term effect of the Act will be to constrain government spending ${ }^{191}$ or merely to increase deficit spending, thereby shifting the resulting tax burden to future generations. ${ }^{192}$ It is clear,

${ }^{190}$ See Auerbach et al., supra note 18, at 1653 (criticizing policy of "[i]ncreasing defense spending while sustaining lower taxes for high-income households" as a "guns and caviar" approach).

191 See State of the Union, supra note 11, at 354 ("Unrestrained government spending is a dangerous road to deficits, so we must take a different path .... You see, the growing surplus exists because taxes are too high and Government is charging more than it needs. The people of America have been overcharged, and on their behalf, I am here asking for a refund.").

192 See Gale \& Potter, supra note 4, at 144 ("[T]ax cuts are not simply a matter of returning unneeded or unused funds to taxpayers, but rather a choice to require other, future taxpayers to cover the long-term deficit, which the tax cut significantly exacerbates... Thus, the issue is not whether taxpayers should have their tax payments returned, but rather which taxpayers - current or future - will be required to pay for the spending obligations incurred by current and past taxpayers."). 
however, that the abolitionists do not have time on their side. As the mounting revenue costs and skewed distributional effects of the Act become clearer, the prospects for making the tax cuts permanent are likely to fade. As the federal budget comes under increasing pressure to meet the costs of preserving social security and medicare while prosecuting a global war on terrorism, the estate tax may reassert its traditional role as a small but important - perhaps indispensable component of the overall tax system. ${ }^{193}$

193 See Gale \& Slemrod, supra note 7, at 58 ("[T]he estate tax may well play a small but important role in the government's portfolio of tax instruments."). 